\title{
In vitro effects of Escherichia coli lipopolysaccharide on the function and gene expression of neutrophils isolated from the blood of dairy cows
}

\author{
X. S. Revelo and M. R. Waldron ${ }^{1}$ \\ Division of Animal Sciences, University of Missouri-Columbia, Columbia 65211
}

\begin{abstract}
The objectives of this study were to investigate the effect of Escherichia coli lipopolysaccharide (LPS) on the function of bovine neutrophils (PMNL) collected from mid lactation cows and determine the differential effects of LPS on gene expression of PMNL purified from early and mid lactation cows. The PMNL from mid lactation cows (187 $\pm 13 \mathrm{~d}$ postpartum) were incubated with $0,1,25$, and $50 \mu \mathrm{g} / \mathrm{mL}$ of LPS for $120 \mathrm{~min}$, and the generation of reactive oxygen species (ROS), PMNL extracellular traps (NET), chemotaxis, and killing of Staphylococcus aureus were determined. Incubation of PMNL with $25 \mu \mathrm{g} / \mathrm{mL}$ of LPS increased intracellular ROS by $79 \%$ in mitogen-stimulated PMNL. Addition of $50 \mu \mathrm{g} / \mathrm{mL}$ of LPS enhanced intracellular ROS by nonstimulated and stimulated PMNL by 184 and $154 \%$, respectively. Nonstimulated PMNL incubated with 25 and $50 \mu \mathrm{g} / \mathrm{mL}$ of LPS had a $105 \%$ increase in NET. Addition of LPS had no effect on subsequent PMNL chemotaxis or killing of Staph. aureus. To examine the effect of LPS on the expression of genes involved in PMNL function and cytokine production, mRNA was purified from PMNL isolated from mid lactation (146 \pm 2 postpartum; $\mathrm{n}=10)$ and early lactation cows $(7 \mathrm{~d}$ postpartum; $\mathrm{n}=10$ ), after a 120 -min incubation with 0 or $50 \mu \mathrm{g} / \mathrm{mL}$ of LPS. Amounts of interleukin-8 (IL-8), tumor necrosis factor $(T N F)$, bactericidal/permeability-increasing protein $(B P I)$, myeloperoxidase $(M P O)$, superoxide dismutase 2 (SOD2), NADPH oxidase 4 (NOX4), Cytochrome b-245, a polypeptide (CYBA), histone H2A/1 (H2A/1), and histone H2B-like $(H 2 B)$ mRNA were determined relative to that of $\beta$-actin by real-time quantitative PCR. Regardless of stage of lactation, PMNL incubated with $50 \mu \mathrm{g} / \mathrm{mL}$ of LPS had 537 and $45 \%$ higher mRNA contents of $I L-8$ and SOD2 compared with $0 \mu \mathrm{g} / \mathrm{mL}$ LPS, respectively. In addition, LPS augmented the expression of TNF, BPI, and CYBA $(2,908,59$, and $158 \%$ compared with controls, respectively) only in PMNL from mid lactation cows.
\end{abstract}

Received June 11, 2011

Accepted December 8, 2011.

${ }^{1}$ Corresponding author: waldronm@missouri.edu
Addition of LPS did not affect mRNA levels of $M P O$, NOX4, H2A/1, or H2B. Independent of LPS treatment, PMNL from mid lactation cows had $99 \%$ higher mRNA contents of $I L-8$ compared with PMNL from early lactation cows. The PMNL from early lactation cows had a $634 \%$ increase in MPO mRNA expression relative to that from mid lactation cows. These results support that LPS directly stimulates PMNL to produce ROS and express NET. In addition, LPS enhances the generation of ROS by PMNL in response to other stimuli and increases the expression of genes encoding inflammatory mediators and enzymes involved in the production of ROS. Finally, reduced PMNL gene expression of $I L-8$ (regardless of LPS activation), TNF, $C Y B A$, and BPI (upon stimulation with LPS) in early lactation may elucidate several mechanisms by which PMNL may become immune-incompetent during this period.

Key words: neutrophil, lipopolysaccharide, immunosuppression

\section{INTRODUCTION}

During IMI with gram-negative bacteria, growth and death of the invading pathogen results in the shedding of the LPS components of the bacterial cell wall (Burvenich et al., 2003). Lipopolysaccharide has a core oligosaccharide, repeated polysaccharide units (Oantigens), and a lipid A domain, which causes the toxic effects of LPS (Hogan and Smith, 2003). In the mammary gland, LPS initiates the inflammatory response in part by stimulating macrophages and monocytes to secrete proinflammatory cytokines into the surrounding environment (Paape et al., 2002). In response to this stimulus, circulating PMNL (or neutrophils) are rapidly recruited to the mammary gland. As an example, infusion of $100 \mu \mathrm{g}$ of Escherichia coli LPS into the quarters of healthy mid lactation cows reduced the number of circulating PMNL by approximately $75 \%$ and resulted in a dramatic influx of somatic cells into the mammary gland as early as $4 \mathrm{~h}$ after the challenge (Bannerman et al., 2003). In the milk of LPS-challenged quarters, PMNL are the predominant cellular population, whereas macrophages and monocytes comprise the majority 
of leukocytes present in the healthy mammary gland (Saad and Ostensson, 1990). The successful migration of PMNL into the mammary gland via chemotaxis and subsequent phagocytosis and killing are crucial for the resolution of IMI (Vangroenweghe et al., 2005). Bovine PMNL use several strategies to destroy the invading pathogen, including microbial uptake, intracellular killing, and the secretion of antimicrobial molecules (e.g., reactive oxygen species, ROS) to the extracellular space (Paape et al., 2003). The PMNL are also capable of releasing granule proteins and decondensed chromatin to form extracellular fibers known as neutrophil extracellular traps (NET) that bind microorganisms, preventing them from distributing throughout the tissue, and killing the pathogens by keeping them in a high local concentration of antimicrobial agents (Brinkmann et al., 2004). The function of bovine PMNL is altered during the periparturient period (Kehrli and Goff, 1989; Cai et al., 1994; Revelo and Waldron, 2010), contributing to the attenuated pathogen-killing capacity observed after calving (Dosogne et al., 2001).

Large amounts of LPS can be released in the infected mammary glands of cows with naturally occurring coliform mastitis (Anri, 1989; Hakogi et al., 1989). Absorption of LPS into the general circulation has been reported 6 to $8 \mathrm{~h}$ after intramammary infusion of 10 mg of E. coli LPS (Ziv et al., 1976) and in cows with naturally occurring gram-negative bacterial mastitis (Hakogi et al., 1989). Mammary macrophages and epithelial cells are presumed to recognize LPS to produce cytokines that initiate the inflammatory response (Burvenich et al., 2007). These cytokines include chemoattractants that recruit circulating PMNL to the infected gland where the phagocytes engulf and destroy invading pathogens. However, PMNL may have secondary but important roles in the innate immune response against gram-negative bacteria. These roles include recognition of LPS and the production of inflammatory mediators including IL-1 $\beta$, IL- 12 , IFN- $\gamma$, IL-8, and tumor necrosis factor- $\alpha$ (TNF- $\alpha$ ) (Sohn et al., 2007b; Worku and Morris, 2009). Mammary macrophages and epithelial cells recognize and bind LPS using their toll-like receptors (TLR) such as TLR-4 assisted by the accessory molecules LPS-binding protein $(\mathbf{L B P})$, cluster of differentiation 14 (CD14), and myeloid differentiation protein 2 (MD-2; De Schepper et al., 2008; Ibeagha-Awemu et al., 2008). Bovine PMNL use a similar mechanism to recognize LPS because they express TLR-4 on their cell surface (Worku and Morris, 2009) and are capable of shedding membrane CD14 upon in vitro exposure to E. coli LPS (Sohn et al., 2007a).

Lipopolysaccharide may have a direct effect on the activation of PMNL in response to the invading pathogen. For example, incubation of human PMNL with
LPS increases their oxidative burst (Forehand et al., 1989; Aida and Pabst, 1990; Böhmer et al., 1992) and phagocytosis of Staphylococcus aureus (Böhmer et al., 1992). In mice, culture of bone marrow PMNL with LPS induces the intracellular ROS-dependent activation of nuclear factor $\kappa \mathrm{B}(\mathbf{N F}-\kappa \mathbf{B})$, a transcription factor that subsequently regulates the gene expression of many proinflammatory cytokines (Asehnoune et al., 2004). In cows, increased ROS generation by PMNL has been reported after incubation of blood PMNL with Pasteurella hemolytica LPS (McClenahan et al., 2000 ) and intramammary infusion of E. coli LPS (Mehrzad et al., 2001). However, in the study by Mehrzad et al. (2001), the increase in ROS and modulation of cell viability were likely influenced by other inflammatory mediators and cytokines rather than just LPS alone. Previous research suggests that LPS per se induces the secretion of cytokines and inflammatory mediators by bovine PMNL (Sohn et al., 2007b; Worku and Morris, 2009). Whether LPS directly influences the mechanisms used by bovine PMNL to eliminate pathogens has not been investigated. Therefore, the objective of this study was to determine the effects of LPS on the functional capacity and gene expression of PMNL isolated from the blood of dairy cows. We hypothesized that (1) a short-term incubation of PMNL with LPS would alter their ROS generation, NET release, chemotaxis, and killing capacity against Staph. aureus; (2) LPS would stimulate the PMNL expression of genes encoding for cytokines and proteins involved in antimicrobial function; and (3) expression of these genes would be reduced in PMNL from early lactation compared with those from mid lactation cows.

\section{MATERIALS AND METHODS}

\section{Blood Donors}

The use and care of all animals were approved by The University of Missouri Animal Care and Use Committee. Only multiparous Holstein cows entering second or greater lactation were used in this study. All cows were free of obvious clinical infection or inflammation, their rectal temperatures were $<39.5^{\circ} \mathrm{C}$, and current SCC $<200,000$ cells $/ \mathrm{mL}$. To determine the effects of LPS on the function of neutrophils, $60 \mathrm{~mL}$ of blood was collected from 7 cows in mid lactation $(187 \pm 13 \mathrm{~d}$ after calving). To investigate the differential effects of LPS on the gene expression of neutrophils from cows relative to their stage of lactation, $120 \mathrm{~mL}$ of blood was collected from 10 cows in mid lactation (146 \pm $2 \mathrm{~d}$ after calving) and 10 cows in early lactation $(7 \mathrm{~d}$ after calving). Blood was collected via coccygeal vessel puncture into evacuated tubes containing acid-citrate 
dextrose (Vacutainer, Becton Dickinson, Franklin Lakes, NJ), inverted 3 times, and stored on ice until laboratory processing ( $<20 \mathrm{~min})$. All functional assays were performed simultaneously on the same day for any given cow.

\section{Reagents}

Percoll was obtained from GE Healthcare BioSciences Corp. (Piscataway, NJ). Lipopolysaccharide from E. coli serotype O55:B5 (strain CDC 1644-70; conjugated to fluorescein isothiocyanate) was obtained from Sigma Chemical Co. (St. Louis, MO). Trizol was acquired from Invitrogen Co. (Carlsbad, CA). Luminol (5-amino-2,3-dihydro-1,4-phthalazinedione; Sigma Chemical Co.) and phorbol 12-myristate,13-acetate (PMA; Sigma Chemical Co.) were prepared as 89.4 $\mathrm{m} M$ and $162.12 \mu M$ stock solutions, respectively, in dimethyl sulfoxide (DMSO). The 5-(6)-chloromethyl$2^{\prime}, 7^{\prime}$-dichlorodihydrofluorescein diacetate acetyl ester

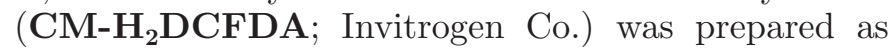
$1,730.7 \mu M$ stock solution in DMSO. Sytox Orange nucleic acid stain was obtained from Invitrogen Co. as a 5 $\mathrm{m} M$ solution in DMSO. All stock solutions were stored at $-20^{\circ} \mathrm{C}$. All working solutions, cell suspensions, and reactions were prepared using endotoxin-free, calciumand magnesium-free Hanks' balanced salt solution (CMF-HBSS; Sigma Chemical Co.) or RPMI-1640 (GIBCO, Grand Island, NY) $+2 \%$ heat-inactivated fetal bovine serum (FBS) and were prewarmed to $37^{\circ} \mathrm{C}$ immediately before their use in the assays. The CMFHBSS and RPMI-1640 were used in our in vitro cellular system to maintain a balanced environment (intra- and extracellular osmolarity, $\mathrm{pH},\left[\mathrm{O}_{2}\right]$, and temperature) and provide the cells with water and inorganic ions essential for normal cell metabolism. The use of HBSS as buffering medium during PMNL-chemiluminescence assays results in maximal light emission and cell activation compared with PBS or Tris (Freitas et al., 2009).

\section{Isolation of Bovine Neutrophils}

Neutrophils were isolated using procedures modified from Weber et al. (2001) as validated in our laboratory. Blood $(10 \mathrm{~mL})$ was aliquoted into $50-\mathrm{mL}$ polypropylene conical tubes (Corning Inc., NY) and centrifuged at $1,000 \times g$ for $20 \mathrm{~min}$ at $4^{\circ} \mathrm{C}$ to separate plasma from the cell pack. Plasma was discarded and the remaining cells were suspended in $35 \mathrm{~mL}$ of CMF-HBSS. The suspension was gently pipetted down the side of a $50-\mathrm{mL}$ polypropylene conical tube containing $10 \mathrm{~mL}$ of 1.084 $\mathrm{g} / \mathrm{mL}$ of Percoll. The cells were then subjected to gradient centrifugation $\left(400 \times g\right.$ for $40 \mathrm{~min}$ at $\left.22^{\circ} \mathrm{C}\right)$. The supernatant, mononuclear cell layer, and Percoll were aseptically aspirated and discarded. The pellet (PMNL and erythrocytes) was retained and erythrocytes were lysed by hypotonic shock. For this procedure, 2 volumes of an ice-cold $10.56 \mathrm{mM} \mathrm{Na} \mathrm{HPO}_{4}, 2.67 \mathrm{mM} \mathrm{NaH} \mathrm{PO}_{4}$ solution were added to 1 volume of cell suspension, and the solution was mixed by gentle aspiration and inversion. Tonicity was restored by the addition of 1 volume of a $10.56 \mathrm{~m} M \mathrm{Na}_{2} \mathrm{HPO}_{4}, 2.67 \mathrm{~m} M \mathrm{NaH}_{2} \mathrm{PO}_{4} 0.43 M$ $\mathrm{NaCl}$ solution. The cell solution was then centrifuged $(850 \times g)$ for $4 \mathrm{~min}$ at $4^{\circ} \mathrm{C}$ and the pellet washed twice by resuspension in $35 \mathrm{~mL}$ of CMF-HBSS and recentrifugation $\left(850 \times g\right.$ for $4 \mathrm{~min}$ at $\left.4^{\circ} \mathrm{C}\right)$. Cells were resuspended in CMF-HBSS (for luminol, CM- $\mathrm{H}_{2} \mathrm{DCFDA}$, chemotaxis, and killing assays) or RPMI-1640 $+2 \%$ heat-inactivated FBS (for NET assay). The PMNL were then enumerated and viability was determined by propidium iodide (Sigma Chemical Co.) exclusion using a Cellometer Vision automatic cell counter (Nexcelom Bioscience LLC, Lawrence, MA). The concentration of cells was adjusted for every assay and the suspensions were kept at $4^{\circ} \mathrm{C}$ until incubation with LPS.

\section{LPS Incubations}

To investigate the effects of LPS on PMNL function, we incubated blood PMNL with 0, 1, 25, and $50 \mu \mathrm{g} /$ $\mathrm{mL}$ of E. coli LPS for 120 min. Similar doses $(0,1,10$, and $100 \mu \mathrm{g} / \mathrm{mL}$ ) have been used to study the effect of LPS on the bovine PMNL production of TNF- $\alpha$, IL-1 $\beta$, IL-12, and IFN- $\gamma$ in vitro (Sohn et al., 2007b), and are within the range of doses often used during experimental intramammary LPS challenges. For the functional assays, working solutions of LPS in CMF-HBSS (luminol, $\mathrm{CM}-\mathrm{H}_{2} \mathrm{DCFDA}$, chemotaxis, and killing assays) or RPMI-1640 + 2\% heat-inactivated FBS (NET assay) were pipetted into polystyrene round-bottomed tubes (Becton Dickinson Labware, Franklin Lakes, NJ) containing $5 \times 10^{6}$ cells $/ \mathrm{mL}$ (luminol and $\mathrm{CM}-\mathrm{H}_{2} \mathrm{DCFDA}$ assays), $3.75 \times 10^{6}$ cells $/ \mathrm{mL}$ (chemotaxis assay), 6.25 $\times 10^{6}$ cells $/ \mathrm{mL}$ (NET assay), and $2 \times 10^{5}$ cells $/ \mathrm{mL}$ (killing assay) to reach final concentrations of $0,1,25$, or $50 \mu \mathrm{g} / \mathrm{mL}$ of LPS. The tubes were then incubated with lids in a humidified incubator $\left(37^{\circ} \mathrm{C}, 5 \% \mathrm{CO}_{2}\right)$ for 120 min while inverted in a Labquake tube rotator (Barnstead-Thermolyne Corp., Dubuque, IA). After incubation, the cell suspensions were mixed by aspiration and the functional assays performed. To determine the effect of LPS on gene expression, a working solution of $250 \mu \mathrm{g} / \mathrm{mL}$ LPS was added to 50-mL polypropylene conical tubes (Corning Inc., Corning, NY) containing purified neutrophils to reach final concentrations of 0 or $50 \mu \mathrm{g} / \mathrm{mL}$ of LPS at a cell concentration of $6 \times 10^{6}$ cells $/ \mathrm{mL}$. The tubes were then placed in a humidified incubator $\left(37^{\circ} \mathrm{C}, 5 \% \mathrm{CO}_{2}\right)$ and incubated for $120 \mathrm{~min}$ 
while inverted in a Labquake tube rotator. After incubation, the cell solutions were centrifuged $(850 \times g)$ for 4 min at $4^{\circ} \mathrm{C}$, and the pellet was resuspended in Trizol at a concentration of $1 \times 10^{7}$ cells $/ \mathrm{mL}$ and stored at $-80^{\circ} \mathrm{C}$ until mRNA extraction.

\section{CM- ${ }_{2}$ DCFDA Fluorescence Assay}

An index of the intracellular neutrophil ROS production was assessed using a $\mathrm{CM}-\mathrm{H}_{2}$ DCFDA fluorescence assay (Revelo and Waldron, 2010). One hundred microliters of cell suspension was pipetted into the wells $(5 \times$ $10^{5}$ cells/well) of white-walled, clear-bottomed 96-well microplates (Corning Inc.). All reactions were carried out in sextuplicate. Ten microliters of $200 \mu M$ CM$\mathrm{H}_{2}$ DCFDA and $30 \mu \mathrm{L}$ of either $400 \mathrm{nM}$ PMA (stimulated cells) or HBSS (nonstimulated cells) were added to all wells. All reactions were then adjusted to $200 \mu \mathrm{L}$ using CMF-HBSS. Fluorescence was measured every 5 min for 240 min with a Synergy HT plate reader (BioTek Instruments Inc., Winooski, VT) at an excitation wavelength of $485 \mathrm{~nm}$ and an emission wavelength of $528 \mathrm{~nm}$. Background values, defined as the mean fluorescence values of $\mathrm{CM}-\mathrm{H}_{2} \mathrm{DCFDA}$ diluted in CMFHBSS, were subtracted from all readings.

\section{Luminol Chemiluminescence Assay}

After incubation with LPS, an index of the total neutrophil ROS production was immediately assessed by a luminol chemiluminescence assay as described by Revelo and Waldron (2010). Fifty microliters of cell suspension was pipetted into the wells $\left(2.5 \times 10^{5}\right.$ cells/ well) of white-walled, clear-bottomed 96-well microplates (Corning Inc.). All reactions were carried out in sextuplicate. Twenty microliters of luminol and 20 $\mu \mathrm{L}$ of either $400 \mathrm{nM}$ PMA (stimulated cells) or HBSS (nonstimulated cells) were added to all wells. All reactions were then adjusted to $200 \mu \mathrm{L}$ using CMF-HBSS. Chemiluminescence (CL) was measured every $5 \mathrm{~min}$ for 240 min with a Synergy HT plate reader (BioTek Instruments Inc.). Background values, defined as the mean CL values of luminol diluted in CMF-HBSS, were automatically subtracted from all readings.

\section{NET Assay}

Neutrophil extracellular trap formation was quantified using Sytox Orange as described by Revelo and Waldron (2010). After PMNL incubation with LPS, 100 $\mu \mathrm{L}$ of cell suspension was pipetted into the wells $(6.25 \times$ $10^{5}$ cells/well) of white-walled, clear-bottomed 96-well microplates (Costar Inc.). All reactions were performed in sextuplicate. Twenty microliters of PMA and $20 \mu \mathrm{L}$ of ionomycin (in RPMI-1640 + $2 \%$ heat-inactivated FBS) to obtain a final concentration of $16.21 \mathrm{n} M$ and $1 \mu M$, respectively, were added to the stimulated set of wells. Forty microliters of RPMI- $1640+2 \%$ heatinactivated FBS were added to the control wells. The plates were then centrifuged $(10 \mathrm{~min}$ at $650 \times \mathrm{g})$ and incubated $\left(37^{\circ} \mathrm{C}\right.$ and $\left.5 \% \mathrm{CO}_{2}\right)$ for $60 \mathrm{~min}$. After incubation, supernatant from the plates was removed, and the wells were stained and kept protected from light with $50 \mu \mathrm{L}$ of $5 \mu \mathrm{M}$ Sytox Orange in CMF-HBSS (15 min at room temperature). The stain was poured off and the wells washed 3 times with $100 \mu \mathrm{L}$ of CMF-HBSS. A plate reader was used to detect fluorescence with an excitation wavelength of $530 \mathrm{~nm}$ and emission wavelength of $580 \mathrm{~nm}$. Background values, defined as the mean fluorescence values of PMA and ionomycin diluted in RPMI-1640, were subtracted from all readings.

\section{Chemotaxis Assay}

Chemotaxis was performed in a 48-well micro-chemotaxis chamber (Neuro Probe Inc., Gaithersburg, MD) according to the manufacturer's recommendations. The wells in the bottom plate of the chamber were filled with $26 \mu \mathrm{L}$ of the chemoattractant IL-8 (100 ng/mL) or CMF-HBSS, previously warmed to $37^{\circ} \mathrm{C}$. A slight positive meniscus was formed when the wells were filled with the chemoattractant. A $25 \times 80 \mathrm{~mm}$ polycarbonate filter (non-polyvinylpyrrolidone-treated, Neuro Probe Inc.) was lowered onto the formed meniscus, allowing the middle portion of the filter to make contact first. The polycarbonate filter had pores with a diameter of $5 \mu \mathrm{m}$ to allow migration and adhesion of PMNL to the underside of the filter where they could be stained and counted. A silicone gasket was then applied on top of the filter and the top component of the microchemotaxis chamber fastened to the bottom chamber. The chamber was prewarmed for $10 \mathrm{~min}$ at $37^{\circ} \mathrm{C}$ before adding the PMNL to the upper chamber. Fifty-five microliters of cell suspension $\left(3.75 \times 10^{6}\right.$ neutrophils $\left./ \mathrm{mL}\right)$ previously incubated with increasing concentrations of LPS was added to the top chamber and incubated at $37^{\circ} \mathrm{C}$ in humidified air with $5 \% \mathrm{CO}_{2}$ for $30 \mathrm{~min}$ to allow the PMNL to migrate toward the chemoattractant. After incubation, the fluid from the top chamber was aspirated and the chamber disassembled. The side of the filter membrane that had faced the upper chamber was rinsed with CMF-HBSS and wiped off 3 times with a wiper blade to remove nonmigrated PMNL. Migrated PMNL were adhered to the side of the filter that had faced the IL-8 (chemoattractant) or CMF-HBSS (control). The filter was immersed in methanol for 10 min, air-dried, and stained in a $3.75 \%$ Giemsa staining solution (Sigma Chemical Co.) for $1 \mathrm{~h}$. Subsequently, 
the membrane was rinsed in Giemsa buffer and placed with the cell side up on a $50 \times 75 \mathrm{~mm}$ microscope slide for drying. The number of PMNL that migrated through the filter was counted under oil immersion on a light microscope by counting the number of neutrophils present in 5 microscope fields at 1,000× magnification. Each sample was run in duplicate. Results are reported as the average number of migrated neutrophils toward IL-8 or CMF-HBSS observed per 5 fields.

\section{Killing Assay}

The killing assay was performed as described by Revelo and Waldron (2010). Staphylococcus aureus Newbould 305 (American Type Culture Collection, Manassas, VA) was inoculated on a blood agar plate (Northeast Laboratory Services Inc., Winslow, ME) and incubated overnight at $37^{\circ} \mathrm{C}$. Ten colonies were transferred from the plate to a sterile tube containing $10 \mathrm{~mL}$ of brain-heart infusion broth (Sigma Chemical Co.) and incubated overnight at $37^{\circ} \mathrm{C}$ at $225 \mathrm{rpm}$ in an orbital shaker. After the overnight incubation, the tube was sonicated to disassociate individual bacterial cells using a sonic dismembrator (Sonifier, Branson Ultrasonics Corp., Danbury, CT) and maintained at $4^{\circ} \mathrm{C}$ to stop bacterial growth. One hundred microliters from this culture was serially diluted in CMF-HBSS, and $100 \mu \mathrm{L}$ of the resulting dilutions were spread on blood agar plates. The stock culture was maintained at $4^{\circ} \mathrm{C}$ and the plates were incubated overnight at $37^{\circ} \mathrm{C}$ to determine the concentration $(\mathrm{cfu} / \mathrm{mL})$ of the stock culture based on the colony counts of the spread plates. Immediately before the initiation of the killing assay, the stock culture was placed in ice and diluted in HBSS to yield a final concentration of $1.6 \times 10^{8} \mathrm{cfu} / \mathrm{mL}$. To assess PMNL killing, $200 \mu \mathrm{L}$ of Staph. aureus $(3.2 \times$ $10^{7} \mathrm{cfu}$ ) and $400 \mu \mathrm{L}$ of pooled, heat-inactivated bovine serum were added to sterile tubes with or without 2 $\times 10^{6}$ PMNL previously incubated with the different doses of LPS (1.4 mL). The ratio of bacteria to PMNL was 16:1. All reactions were performed in triplicate. The samples were placed on a Labquake tube rotator for $60 \mathrm{~min}$ at $37^{\circ} \mathrm{C}$. These reactions were then placed in ice and sonicated with a sonic dismembrator for $15 \mathrm{~s}$ at amplitude of $20 \%$. Rupture of the PMNL was verified by microscopic examination. Sonication does not affect bacterial viability (Rinaldi et al., 2006; X. S. Revelo and M. R. Waldron, unpublished observation). A 100$\mu \mathrm{L}$ aliquot from each sonicated reaction was serially diluted in CMF-HBSS, and $100-\mu \mathrm{L}$ quantities of the resulting dilutions were spread on blood agar plates. The plates were incubated overnight at $37^{\circ} \mathrm{C}$ and the colonies enumerated. The percentage of bacteria killed was determined by calculating the difference in the number of bacteria incubated in the absence and presence of PMNL and dividing this difference by the number of colonies when bacteria were incubated in the absence of PMNL.

\section{RNA Isolation from PMNL and Reverse Transcription}

Total cellular RNA was isolated from neutrophils purified from $120 \mathrm{~mL}$ of blood using $1 \mathrm{~mL}$ of Trizol reagent per $7.5 \times 10^{6}$ cells, according to the manufacturer recommendations. The concentration and purity of RNA was determined with a ND-1000 NanoDrop spectrophotometer (NanoDrop Technologies, Wilmington, DE). Genomic DNA was removed by DNase digestion using the Turbo DNase kit (Applied Biosystems/ Ambion, Foster City, CA). The integrity of RNA was assessed by gel electrophoresis $(0.8 \%$ agarose gel in 0.09 $M$ Tris-borate and $0.002 M$ EDTA buffer with $0.5 \mu \mathrm{g} /$ $\mathrm{mL}$ ethidium bromide) and the RNA was stored at $-80^{\circ} \mathrm{C}$. Reverse transcription of $400 \mathrm{ng}$ of total cellular RNA to cDNA was performed using the High Capacity cDNA Reverse Transcription kit (Applied Biosystems).

\section{Target Genes, Primer Sets, and RT-PCR}

The amount of $\beta$-actin $(\boldsymbol{A C T B}), I L-8, T N F$, bactericidal/permeability-increasing protein $(\boldsymbol{B P I})$, myeloperoxidase $(\boldsymbol{M P O})$, superoxide dismutase 2 (SOD2), NADPH oxidase 4 (NOX4), Cytochrome $b-245 \alpha$ polypeptide $(\boldsymbol{C} \boldsymbol{Y} \boldsymbol{B} \boldsymbol{A})$, histone H2A.1 transcript variant $1(\boldsymbol{H}$ 2 $\boldsymbol{A} / \mathbf{1})$ and histone H2B-like $(\boldsymbol{H}$ 2 B $)$ mRNA in neutrophils after a 120 -min incubation with 0 or 50 $\mu \mathrm{g} / \mathrm{mL}$ of LPS were measured by real-time quantitative PCR (RT-PCR). The main biological functions of these genes are indicated in Table 1. Primer sets were designed using PrimerQuest (Integrated DNA Technologies, Coralville, IA) based on publicly available bovine mRNA sequences by the National Center of Biotechnology Information (NCBI; National Center of Biotechnology Information, 2010). The RT-PCR products from the primer sets were sequenced by the University of Missouri DNA Core Laboratory and the sequences aligned against NCBI sequences to verify the amplification of genes of interest using the Basic Local Alignment Search Tool (http://blast.ncbi.nlm. nih.gov/; NCBI, 2010). Features of the primers used in RT-PCR are reported in Table 2 . The RT-PCR reactions $(10 \mu \mathrm{L})$ were performed using Power SYBR Green PCR Master Mix (Applied Biosystems) with $1 \mu M$ concentrations of forward and reverse primers and 1 $\mu \mathrm{L}$ of cDNA sample. Reactions included a no-template control and were performed in triplicate. SYBR green fluorescence was quantified by the ABI Prism 7500 Sequence Detector (Applied Biosystems). Machine set- 
tings consisted of an initial temperature of $50^{\circ} \mathrm{C}$ for $2 \mathrm{~min}$, a polymerase activation temperature of $95^{\circ} \mathrm{C}$ for $10 \mathrm{~min}$ followed by $40 \mathrm{PCR}$ cycles consisting of 2 stages: (1) melting at $95^{\circ} \mathrm{C}$ for $15 \mathrm{~s}$ and (2) annealing and extension at $60^{\circ} \mathrm{C}$ for $1 \mathrm{~min}$. Analysis of amplification plots was performed by the Sequence Detection Software (Applied Biosystems). One plate was used for all cDNA samples for each primer set. Changes in gene expression relative to the reference gene $A C T B$ were calculated by the $2^{-\Delta \Delta \mathrm{CT}}$ method using the mean cycle threshold (CT) values obtained from all RT-PCR experiments (Livak and Schmittgen, 2001). Relative fold changes in gene expression were assessed by calculating the difference between the $\mathrm{CT}$ values of $A C T B$ and that of the target gene $(\Delta \mathbf{C T})$. Expression of $A C T B$ was not affected by LPS treatment or stage of lactation $(P>0.20)$. To obtain $\Delta \Delta \mathrm{CT}$ values, the mean $\Delta \mathrm{CT}$ of nonactivated PMNL from early lactation cows was used as the calibrator for samples from early lactation cows. In consistency, the mean $\Delta \mathrm{CT}$ of nonactivated PMNL from mid lactation cows was used as the calibrator for samples from mid lactation cows. Fold changes in the expression of target genes normalized to $A C T B$ and relative to nonactivated PMNL within the same physiological state were calculated by the equation $2^{-\Delta \Delta \mathrm{CT}}$. These values were used in the statistical analysis.

\section{Statistical Analysis for the Neutrophil Functional Assays}

The experiment was conducted as a completely randomized design with cow as the experimental unit. Data were analyzed by ANOVA as a mixed model using the mixed procedure (SAS Institute, 2001). Two mixed models were used for the luminol- and CM- $\mathrm{H}_{2}$ DCFDAbased assays involving multiple measurements of CL or fluorescence over time. One included the repeated statement for assessment of the consecutive LPS and LPS by time relative to cell-activation interaction effects (Littell et al., 1998). The repeated statement used time as the variable, with cow within treatment as the subject and a compound symmetry covariance structure. The second mixed model used calculated areas under the curves (AUC) generated using the least squares estimates for CL or fluorescence at each time point. The AUC were calculated from plotted data points for each experimental condition using the expand procedure of SAS with cubic spline interpolation and the trapezoid rule (SAS Institute, 2001).

The variables in the model statements included LPS treatment, cell activation/inhibition (luminol, CM- $\mathrm{H}_{2} \mathrm{DCFDA}$, and NET assays), time (luminol and CM- $\mathrm{H}_{2}$ DCFDA assays), chemoattractant (chemotaxis), and all interactions. Least squares means and standard errors were generated using the LSMeans statement in conjunction with the pdiff option (SAS Institute, 2001). Tukey's multiple comparison test was used to assess specific treatment differences for those variables shown to have significant overall treatment effects in the ANOVA. All reported means are the adjusted least squares means \pm standard error of the mean and the significance was declared when $P<0.05$.

\section{Statistical Analysis for Quantitative RT-PCR}

The analysis of relative fold changes in the expression of target genes was conducted as a completely randomized split-plot design with cow as the experimental unit. Cows were divided according to their stage of lactation into early or mid lactation groups. Further, PMNL from each cow were randomly assigned to in vitro incubations with either 0 or $50 \mu \mathrm{g} / \mathrm{mL}$ of LPS.

Table 1. Gene symbol, description, and relevant biological functions or processes ${ }^{1}$

\begin{tabular}{|c|c|c|}
\hline Symbol & Description & Biological functions or processes ${ }^{2}$ \\
\hline$I L-8$ & Interleukin 8 & Neutrophil activation-chemotaxis, cell adhesion regulation \\
\hline TNF & Tumor necrosis factor & $\begin{array}{l}\text { Cytokine activity, transcription activator-suppressor, } \\
\text { inflammatory response, leukocyte tethering or rolling }\end{array}$ \\
\hline$B P I$ & $\begin{array}{l}\text { Bactericidal/permeability- } \\
\text { increasing protein }\end{array}$ & Lipopolysaccharide binding, response to bacterium, regulation of cytokine production \\
\hline$M P O$ & Myeloperoxidase & Mitochondrial protein with peroxidase activity \\
\hline$C Y B A$ & Cytochrome $b-245, \alpha$ polypeptide & Cytochrome complex assembly, respiratory burst, superoxide anion generation \\
\hline$H 2 A / 1$ & Histone H2A.1, transcript variant 1 & $\begin{array}{l}\text { Maintains nucleosome structural integrity, chromatin condensation } \\
\text { and binding of chromatin associated proteins }\end{array}$ \\
\hline$H 2 B$ & Histone H2B-like & $\begin{array}{l}\text { Maintains nucleosome structural integrity, chromatin condensation } \\
\text { and binding of chromatin associated proteins }\end{array}$ \\
\hline
\end{tabular}

${ }^{1}$ National Center for Biotechnology Information (NCBI).

${ }^{2}$ Entrez Gene, NCBI. 
Table 2. Accession number, primer sequences, and percentage of similarity between amplified real time-PCR products and publicly available sequences by the National Center for Biotechnology Information (NCBI)

\begin{tabular}{|c|c|c|c|}
\hline Symbol & Accession number & Primers $^{1}\left(5^{\prime}\right.$ to $\left.3^{\prime}\right)$ & Similarity $^{2}(\%)$ \\
\hline \multirow[t]{2}{*}{$A C T B$} & \multirow[t]{2}{*}{ AY141970.1 } & F: 5'-AGATGTGGATCAGCAAGCAGGAGT-3' & \multirow[t]{2}{*}{96} \\
\hline & & R: 5'-AGCTAACAGTCCGCCTAGAAGCAT-3' & \\
\hline \multirow[t]{2}{*}{$I L-8$} & \multirow[t]{2}{*}{ NM_173925.2 } & F: 5'-GGTGCAGAAGGTTGTGCAGGTATT-3' & \multirow[t]{2}{*}{97} \\
\hline & & R: 5'-ACACCAGACCCACACAGAACATGA-3' & \\
\hline \multirow[t]{2}{*}{$T N F$} & \multirow[t]{2}{*}{ NM_173966.2 } & F: 5'-TCAACTCTCCCTTCCTGCCAATGT-3' & \multirow[t]{2}{*}{98} \\
\hline & & R: 5'-AGTTTGTGTCTCCCAGGACACCTT-3' & \\
\hline \multirow[t]{2}{*}{$B P I$} & \multirow[t]{2}{*}{ NM_173895.2 } & F: 5'-AACCTTTCTGTGGTTGTTGGTGCC-3' & \multirow[t]{2}{*}{96} \\
\hline & & R: 5'-TGATGACAGACTGCAGCGACTCAA-3' & \\
\hline \multirow[t]{2}{*}{$M P O$} & \multirow[t]{2}{*}{ NM_001113298.1 } & F: 5'-TCGATACCAACCTATGCAGCCCAA-3' & \multirow[t]{2}{*}{97} \\
\hline & & R: 5'-ATTTGGTTCTGGCGGTTCAGCTTC-3' & \\
\hline \multirow[t]{2}{*}{ SOD2 } & \multirow[t]{2}{*}{ NM_174034.2 } & F: 5'-TTGCTGGAAGCCATCAAACGTGAC-3' & \multirow[t]{2}{*}{100} \\
\hline & & R: 5'-AATCTGTAAGCGTCCCTGCTCCTT-3' & \\
\hline \multirow[t]{2}{*}{$\mathrm{NOX}_{4}$} & \multirow[t]{2}{*}{ AY354499.1 } & F: 5'-ACTCTGCTGGATGACTGGAAACCA-3' & \multirow[t]{2}{*}{96} \\
\hline & & R: 5'-AGAGTAAGTCTGCAAACCAGCGGA-3' & \\
\hline \multirow[t]{2}{*}{$C Y B A$} & \multirow[t]{2}{*}{ NM_174034.2 } & F: 5'-TGGCGTCCGGTCTAATCCTTATCA-3' & \multirow[t]{2}{*}{97} \\
\hline & & R: 5'-ACCACTCTGGTCAGGTACTTCTGT-3' & \\
\hline \multirow[t]{2}{*}{$H 2 A / 1$} & \multirow[t]{2}{*}{ XM_583411.4 } & F: 5'-TCACCATAAGGCCAAGGGCAAGTA-3' & \multirow[t]{2}{*}{99} \\
\hline & & R: 5'-ACACTCTGGATCGAGGCATCTCTT-3' & \\
\hline \multirow[t]{2}{*}{ H2B } & \multirow[t]{2}{*}{ NM_001114854.1 } & F: 5'-CGCATTACAACAAGCCCTCGACTA-3' & \multirow[t]{2}{*}{91} \\
\hline & & R: 5'-AGCTGGTATACTTGGTGACAGCCT-3' & \\
\hline
\end{tabular}

Extreme observations were detected using PROC REG (SAS Institute, 2001) and removed from the data set if they presented at least 3 of the following characteristics: standardized residual $\left(\mathrm{r}_{\mathrm{i}}\right)>2$ standard deviations, high leverage $\left(\mathrm{h}_{\mathrm{ii}} \geq 2 \mathrm{pn}^{-1}\right.$, where $\mathrm{n}=$ number of observations and $\mathrm{p}=$ number of parameters), possible undue influence $\left[\right.$ DFITTS $_{\mathrm{i}} \geq 2\left(\sqrt{ }_{\mathrm{pn}^{-1}}\right)^{-1}$, DFBETAS $_{\mathrm{i}}$ $\geq 2(\sqrt{ } \mathrm{n})^{-1}$, Cook's distance $\left(\mathrm{D}_{\mathrm{i}}\right)>1$, and ratio of generalized variances $\left(\right.$ COVRATIO $\left._{\mathrm{i}}\right)<1-3 \mathrm{pn}^{-1}$ or $>1+$ $3 \mathrm{pn}^{-1}$ (Kaps and Lamberson, 2004). The distribution of all gene expression data was examined using the Capability procedure of SAS (SAS Institute, 2001). Relative fold changes data from all genes failed the goodness-offit tests for normality $(P<0.05)$. However, the data fitted a lognormal distribution $(P>0.05)$. Therefore, gene expression data were analyzed by ANOVA as a generalized linear mixed model implemented in PROC GLIMMIX (SAS Institute, 2001), which allows for nonnormally distributed data without prior transformation. The variables in the model statements included LPS treatment, stage of lactation and their interaction. The lognormal distribution was specified in the model statement using the DIST and LINK functions of SAS. Least squares means and standard errors were generated using the LSMeans statement in conjunction with the pdiff option of SAS. Tukey's multiple comparison test was used to assess specific treatment differences for those variables shown to have significant overall treatment effects in the ANOVA. For ANOVA in which the main or interaction effects were significant but Tukey's multiple comparison test revealed no differences between means, orthogonal contrast analysis was used to detect specific treatment differences. All reported means are the adjusted least squares means \pm SEM on the logarithmic scale. Significance was declared when $P$ $<0.05$. The percentage changes in gene expression in response to LPS treatment or stage of lactation were calculated by dividing the difference between final and initial by the initial relative gene expression multiplied by 100 . These percentages were calculated using raw units obtained after back-transformation of the least squares means in the logarithmic scale.

\section{RESULTS}

\section{Intracellular ROS Production}

Changes in CM- $\mathrm{H}_{2}$ DCFDA-derived fluorescence, an index of the PMNL intracellular generation of ROS, were observed $15 \mathrm{~min}$ after the initiation of the assay (Figure 1A). The $\mathrm{CM}-\mathrm{H}_{2} \mathrm{DCFDA}$-derived fluorescence from PMA-activated PMNL incubated with 25 and 50 $\mu \mathrm{g} / \mathrm{mL}$ of $E$. coli LPS was clearly elevated compared with that of PMNL treated with 0 and $1 \mu \mathrm{g} / \mathrm{mL}$ as early as $25 \mathrm{~min}$ after cell activation with PMA. All treatments continued to increase until $240 \mathrm{~min}$ after cell activation (time effect, $P<0.001$ ). At the end of the assay (min 240), the CM- $\mathrm{H}_{2} \mathrm{DCFDA}$-derived fluorescence of PMA-activated PMNL incubated with 25 and $50 \mu \mathrm{g} / \mathrm{mL}$ LPS increased by 63 and $118 \%$ com- 
pared with that of PMNL treated with $0 \mu \mathrm{g} / \mathrm{mL}$ of LPS (Figure 1A; LPS effect, $P<0.001$; LPS $\times$ time effect, $P<0.001 ;$ LPS $\times$ time $\times$ cell activation effect $P$ $<0.001)$. In nonactivated PMNL, the CM- $\mathrm{H}_{2}$ DCFDAderived fluorescence from cells incubated with 25 and $50 \mu \mathrm{g} / \mathrm{mL}$ of $E$. coli LPS initiated to increase compared with that of PMNL treated with 0 and $1 \mu \mathrm{g} / \mathrm{mL} 40 \mathrm{~min}$ after the initiation of the assay. At the end of the assay (min 240), the $\mathrm{CM}-\mathrm{H}_{2}$ DCFDA-derived fluorescence of nonactivated PMNL incubated with 25 and $50 \mu \mathrm{g} / \mathrm{mL}$ LPS increased by 82 and $167 \%$ compared with the fluorescence of nonactivated PMNL treated with $0 \mu \mathrm{g} / \mathrm{mL}$ of LPS (Figure 1A; LPS effect, $P<0.001 ;$ LPS $\times$ time effect, $P<0.001$ ). No difference was observed between the $\mathrm{CM}-\mathrm{H}_{2} \mathrm{DCFDA}$-derived fluorescence of PMNL treated with 0 and $1 \mu \mathrm{g} / \mathrm{mL}$ of LPS in nonactivated and PMA-activated PMNL.

Areas under the curves were generated from CM$\mathrm{H}_{2}$ DCFDA-derived fluorescence plotted data points for each LPS dose and cell activation status (Figure 1B). Activation of PMNL with PMA augmented the AUC calculated from $\mathrm{CM}-\mathrm{H}_{2} \mathrm{DCFDA}$-derived fluorescence values, regardless of LPS concentration (cell activation effect, $P<0.001)$. Addition of LPS increased the CM$\mathrm{H}_{2}$ DCFDA-derived fluorescence (AUC) in nonactivated and PMA-activated PMNL (Figure 1B; LPS effect, $P<0.001$, LPS $\times$ cell activation effect, $P<0.001)$. In nonactivated PMNL, $25 \mu \mathrm{g} / \mathrm{mL}$ of LPS tended to increase the AUC relative to $0 \mu \mathrm{g} / \mathrm{mL}$ LPS (88\% increase, $P=0.064)$. Addition of $50 \mu \mathrm{g} / \mathrm{mL}$ of LPS increased the $\mathrm{CM}-\mathrm{H}_{2}$ DCFDA-derived fluorescence (AUC) by $184 \%$ compared with $0 \mu \mathrm{g} / \mathrm{mL}(P<0.001)$. No difference in $\mathrm{CM}-\mathrm{H}_{2} \mathrm{DCFDA}$-derived fluorescence (AUC) was detected between 0 and $1 \mu \mathrm{g} / \mathrm{mL}$ of LPS $(P=$ 1.000). In PMA-activated PMNL, 25 and $50 \mu \mathrm{g} / \mathrm{mL}$ of LPS increased the CM- $\mathrm{H}_{2} \mathrm{DCFDA}$-derived fluorescence (AUC) compared with $0 \mu \mathrm{g} / \mathrm{mL}$ of LPS (79 and $154 \%$, respectively; $P<0.001$ ). In contrast, no difference was detected between the $\mathrm{CM}-\mathrm{H}_{2} \mathrm{DCFDA}$-derived fluorescence (AUC) of PMA-activated PMNL treated with 0 and $1 \mu \mathrm{g} / \mathrm{mL}$ of LPS $(P=0.999)$.

\section{Total ROS Production}

In PMA-activated PMNL, luminol-derived CL started to increase 10 min after cell activation, continued to augment to reach a peak between 75 and 80 min after stimulation, and slightly declined thereafter in PMAactivated PMNL (Figure 2A; time effect, $P<0.001$ ). We did not detect an LPS $\times$ time interaction effect $(P$ $=1.000)$ or LPS $\times$ time $\times$ cell activation effect $(P=$ $0.995)$ but did detect an LPS treatment effect $(P<$ 0.001). The PMA-activated PMNL incubated with 25 and $50 \mu \mathrm{g} / \mathrm{mL}$ of LPS had increased luminol-derived
CL as early as 10 min after PMA stimulation and peaked at values 14 and $35 \%$ higher than $0 \mu \mathrm{g} / \mathrm{mL}$ of LPS (Figure 2A, $P<0.05$ ). This increase in luminoldependent CL in PMNL incubated with 25 and $50 \mu \mathrm{g} /$ $\mathrm{mL}$ of LPS persisted until 240 min after cell activation. In contrast, the luminol-derived CL of PMA-activated PMNL treated with $1 \mu \mathrm{g} / \mathrm{mL}$ of LPS was not different compared with that of PMA-activated PMNL incubated with $0 \mu \mathrm{g} / \mathrm{mL}$ LPS (Figure $2 \mathrm{~A} ; P=0.141$ ). In nonactivated PMNL, increases in luminol-derived CL of PMNL treated with 25 and $50 \mu \mathrm{g} / \mathrm{mL}$ of LPS were observed 100 and $30 \mathrm{~min}$ after the initiation of the assay, relative to PMNL incubated with $0 \mu \mathrm{g} / \mathrm{mL}$ of LPS (Figure 2A; treatment effect, $P<0.001$; time effect $P<0.001$ ). At the end of the assay (min 240), the luminol-derived CL of nonactivated PMNL incubated with 25 and $50 \mu \mathrm{g} / \mathrm{mL}$ LPS increased by 42 and $105 \%$ compared with the fluorescence of nonactivated PMNL treated with $0 \mu \mathrm{g} / \mathrm{mL}$ of LPS (Figure 2A; treatment effect, $P<0.001$ ).

Areas under the curves were generated from luminolderived CL plotted data points for each LPS dose and cell activation status (Figure 2B). Independently of LPS dose, activation of PMNL with PMA increased the luminol-derived CL (AUC) relative to nonstimulated PMNL (cell activation effect, $P<0.001$ ). No differences in AUC generated from CL measurements over time were detected between different doses of LPS, relative to the activation cell status (Figure 2B; LPS effect, $P=$ 0.099; LPS $\times$ cell activation effect, $P=0.975)$.

\section{NET Expression}

Activation of PMNL with $16.21 \mathrm{n} M$ PMA augmented NET release regardless of LPS concentration (Figure 3; PMA-activation effect, $P<0.001)$. An LPS $\times$ activation interaction effect on NET release was detected $(P$ $=0.014)$. In nonactivated PMNL, NET expression by PMNL incubated with 25 and $50 \mu \mathrm{g} / \mathrm{mL}$ of LPS was $105 \%$ higher than that with $0 \mu \mathrm{g} / \mathrm{mL}$ LPS $(P<0.05)$. However, no difference in NET expression by PMNL was detected between 1 and $0 \mu \mathrm{g} / \mathrm{mL}$ of LPS $(P=$ $0.768)$ or 50 and $25 \mu \mathrm{g} / \mathrm{mL}$ of LPS $(P=1.000)$ in nonactivated PMNL. The release of NET did not differ among any of the LPS doses when the PMNL were activated by PMA $(P>0.20)$.

\section{Neutrophil Chemotaxis and Bactericidal Ability}

Independently of LPS dose, an average of 80 to 110 PMNL per microscopic field at $1,000 \times$ were found in membranes, after migration toward IL-8 (directed chemotaxis), whereas fewer than $5 \mathrm{PMNL} /$ field were 
A

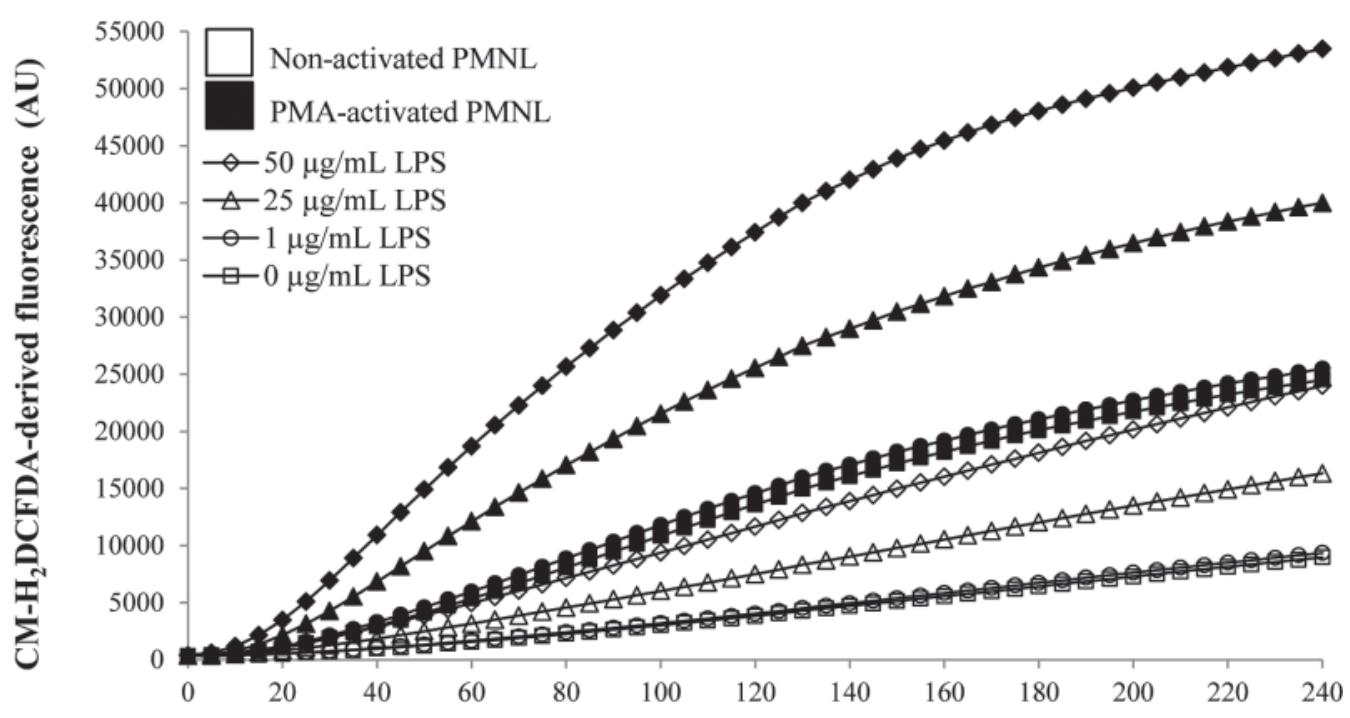

Time relative to activation $(\mathrm{min})$

B

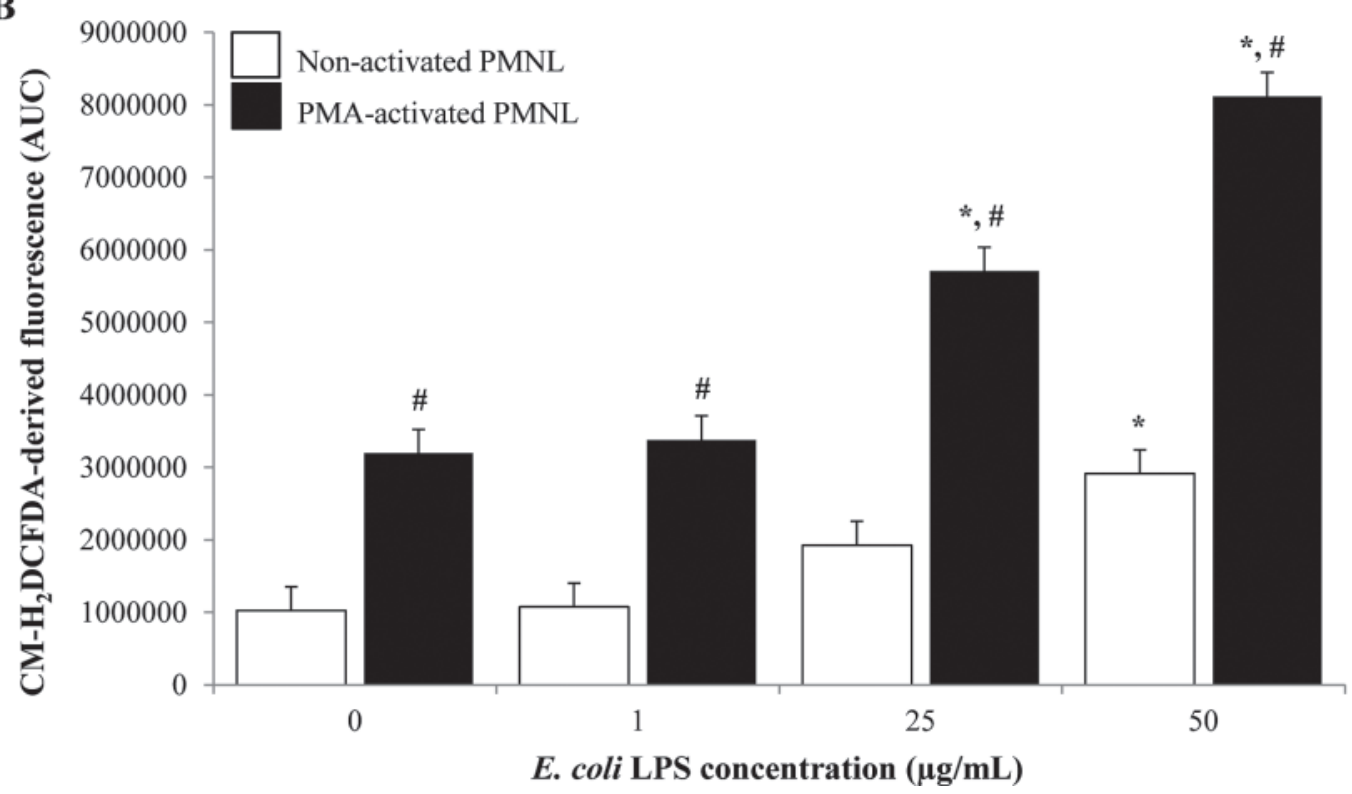

Figure 1. Effect of Escherichia coli LPS on an index of the intracellular reactive oxygen species (ROS) production by bovine PMNL. The PMNL were collected from the blood of cows in mid lactation $(\mathrm{n}=7)$ and incubated with $0,1,25$, or $50 \mu \mathrm{g} / \mathrm{mL}$ of LPS for $120 \mathrm{~min}$ Subsequently, the 5-(6)-chloromethyl-2',7'-dichlorodihydrofluorescein diacetate acetyl ester $\left(\mathrm{CM}-\mathrm{H}_{2} \mathrm{DCFDA}\right)$-derived fluorescence was measured every 5 min over a 240-min period after addition of phorbol 12-myristate,13-acetate (PMA, 400 nM; PMA-activated PMNL) or Hanks' balanced salt solution (HBSS, nonactivated PMNL). Fluorescence values of wells without PMNL (containing HBSS and reagents only) were subtracted from fluorescence measurements of wells with PMA-activated and nonactivated PMNL at every time point. (A) CM- $\mathrm{H}_{2} \mathrm{DCFDA}$-derived fluorescence in arbitrary units (AU) from nonactivated and PMA-activated PMNL measured every 5 min over a 240-min period; ANOVA with a repeated-measures design was used to detect differences between treatments (LPS effect, $P<0.001 ;$ time effect, $P<0.001 ;$ LPS $\times$ time interaction effect, $P<0.001$, LPS $\times$ time $\times$ cell activation effect, $P<0.001$ ). (B) Areas under the curves (AUC) calculated from plotted CM$\mathrm{H}_{2}$ DCFDA-derived measurements for nonactivated and PMA-activated PMNL. Twenty-five and $50 \mu \mathrm{g} / \mathrm{mL}$ of LPS increased total ROS production by PMA-activated PMNL (LPS effect, $P<0.001$; activation effect, $P<0.001$; LPS $\times$ activation effect, $P<0.001$ ). Error bars represent the standard error of the mean. *Bars differ from $0 \mu \mathrm{g} / \mathrm{mL}$ of LPS within the same activation status at $P<0.05$ (Tukey); ${ }^{\#}$ bars differ from nonactivated PMNL within the same LPS dose at $P<0.05$ (Tukey).

counted in membranes after random migration in response to CMF-HBSS (Figure 4; chemoattractant effect, $P<0.001)$. Addition of LPS had no effect on the chemotactic ability of PMNL toward IL-8 or CMF-HBSS (Figure 4; LPS effect, $P=0.378$; LPS $\times$ chemoattractant effect, $P=0.513$ ). 


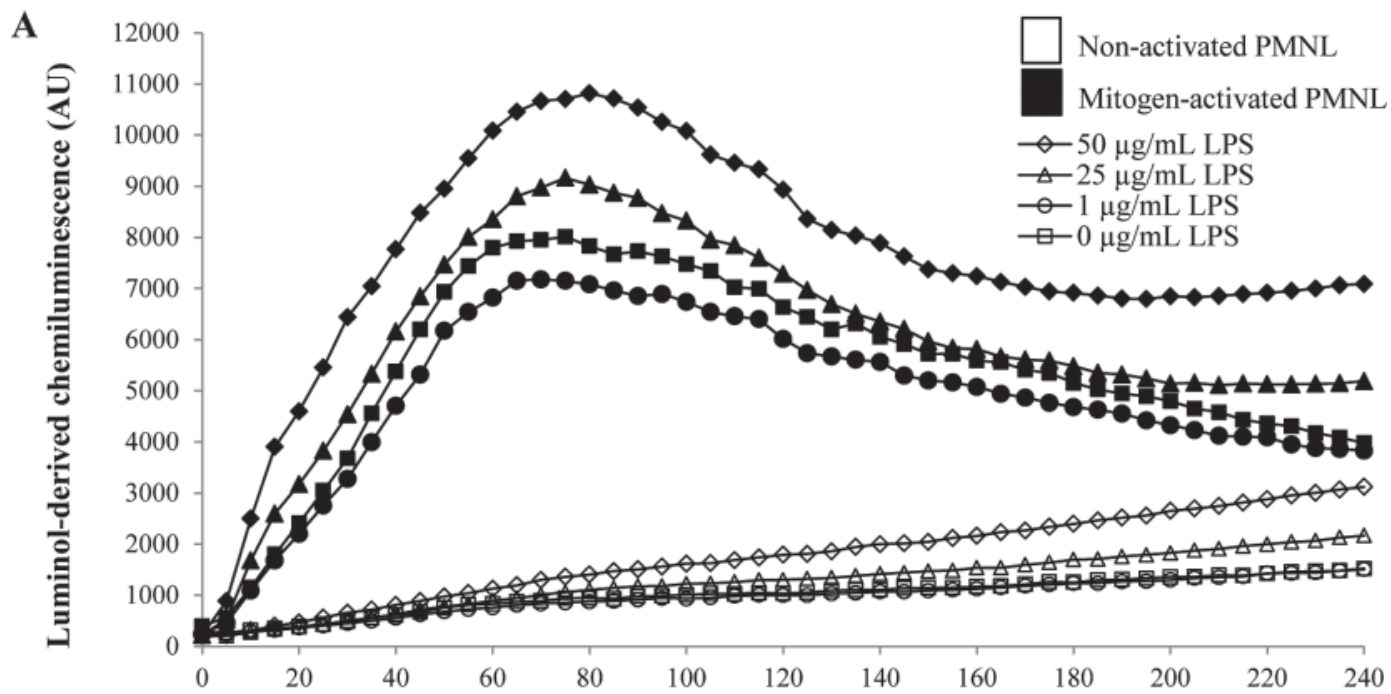

Time relative to activation $(\mathrm{min})$

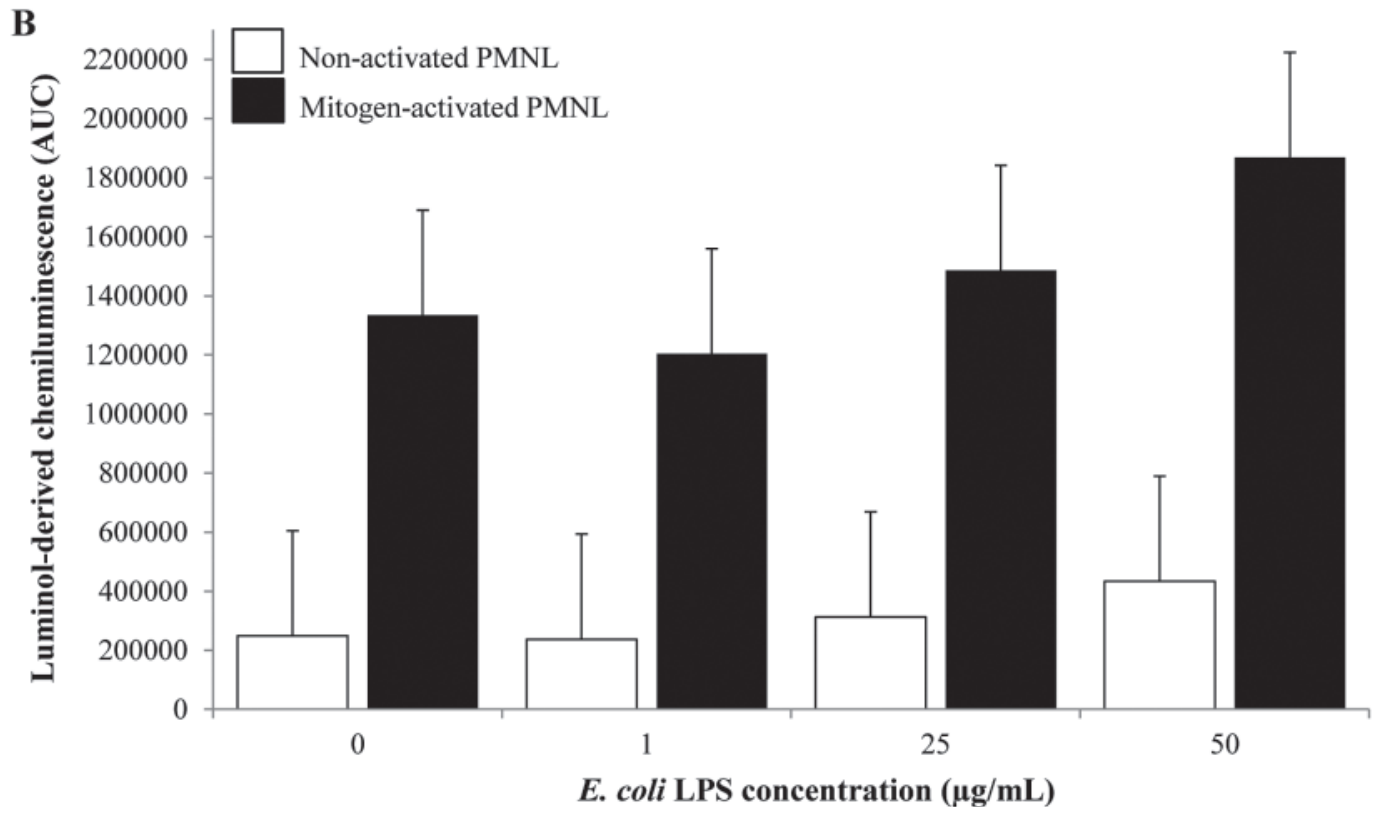

Figure 2. Effect of Escherichia coli LPS on an index of the total reactive oxygen species (ROS) production by bovine PMNL. The PMNL were collected from the blood of cows in mid lactation $(\mathrm{n}=7)$ and incubated with $0,1,25$, or $50 \mu \mathrm{g} / \mathrm{mL}$ of LPS for $120 \mathrm{~min}$. Subsequently, the luminol-derived chemiluminescence (CL) was measured every 5 min over a 240-min period after addition of phorbol 12-myristate,13-acetate (PMA, 400 nM; PMA-activated PMNL) or Hanks' balanced salt solution (HBSS, nonactivated PMNL). The CL values of wells without PMNL (containing HBSS and reagents only) were subtracted from fluorescence measurements of wells with PMA-activated and nonactivated PMNL at every time point. (A) Luminol-derived CL in arbitrary units (AU) from nonactivated and PMA-activated PMNL measured every 5 min over a 240-min period after activation of PMNL with PMA; ANOVA with a repeated measures design was used to detect differences between treatments (LPS effect, $P<0.001$; time effect, $P<0.001 ;$ LPS $\times$ time interaction effect, $P=1.000 ;$ LPS $\times$ time $\times$ cell activation effect, $P=0.995$ ). (B) Areas under the curves (AUC) calculated from plotted luminol-derived CL measurements for nonactivated and PMA-activated PMNL (activation effect, $P<0.001)$. Error bars represent the standard error of the mean.

Figure 5 indicates the killing ability of PMNL against Staph. aureus after incubation with $0,1,25$ and $50 \mu \mathrm{g} / \mathrm{mL}$ of $E$. coli LPS. In average, PMNL killed between 35 and $45 \%$ of bacteria during the 1 -h co- incubation across all LPS concentrations. Addition of LPS had no effect on the bactericidal ability of PMNL against Staph. aureus (Figure 5; LPS effect, $P$ $=0.686)$. 


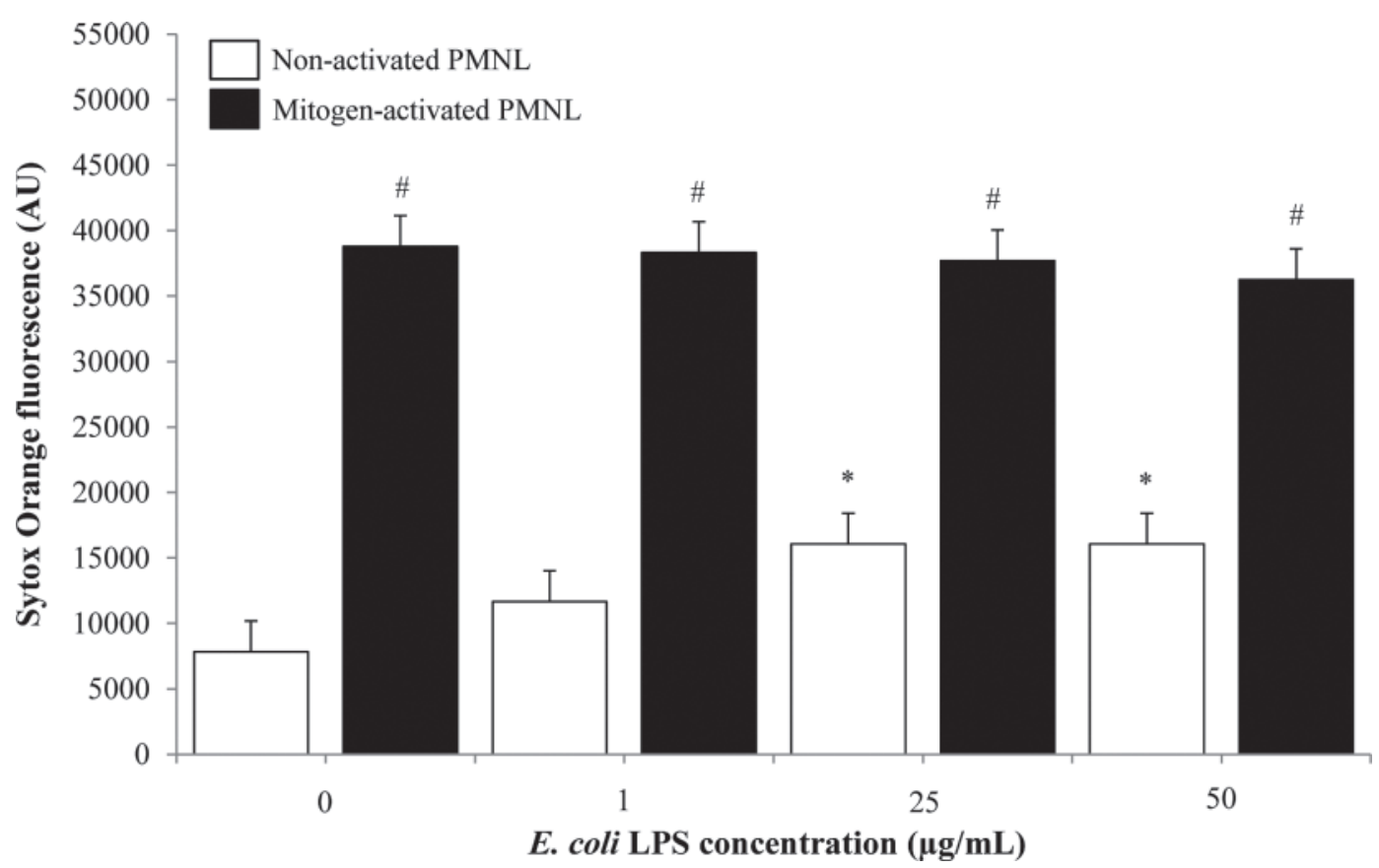

Figure 3. Effect of Escherichia coli LPS on neutrophil extracellular traps expression (NET). The PMNL were collected from the blood of cows in mid lactation $(\mathrm{n}=7)$ and incubated with $0,1,25$, or $50 \mu \mathrm{g} / \mathrm{mL}$ of LPS for $120 \mathrm{~min}$. Bars represent mean fluorescence of cells stained with Sytox Orange (Invitrogen Co., Eugene, OR) after a 1-h incubation with 0 (nonactivated PMNL) or $16.21 \mathrm{n} M$ of phorbol 12-myristate,13acetate (PMA-activated PMNL). Twenty-five and $50 \mu \mathrm{g} / \mathrm{mL}$ of LPS increased NET expression in nonactivated PMNL (LPS $\times$ activation effect, $P=0.014)$. Error bars represent the standard error of the mean. ${ }^{*}$ Bars differ from $0 \mu \mathrm{g} / \mathrm{mL}$ of LPS within their activation status at $P<0.05$ (Tukey); ${ }^{\#}$ bars differ from nonactivated PMNL within the same LPS dose at $P<0.05$ (Tukey).

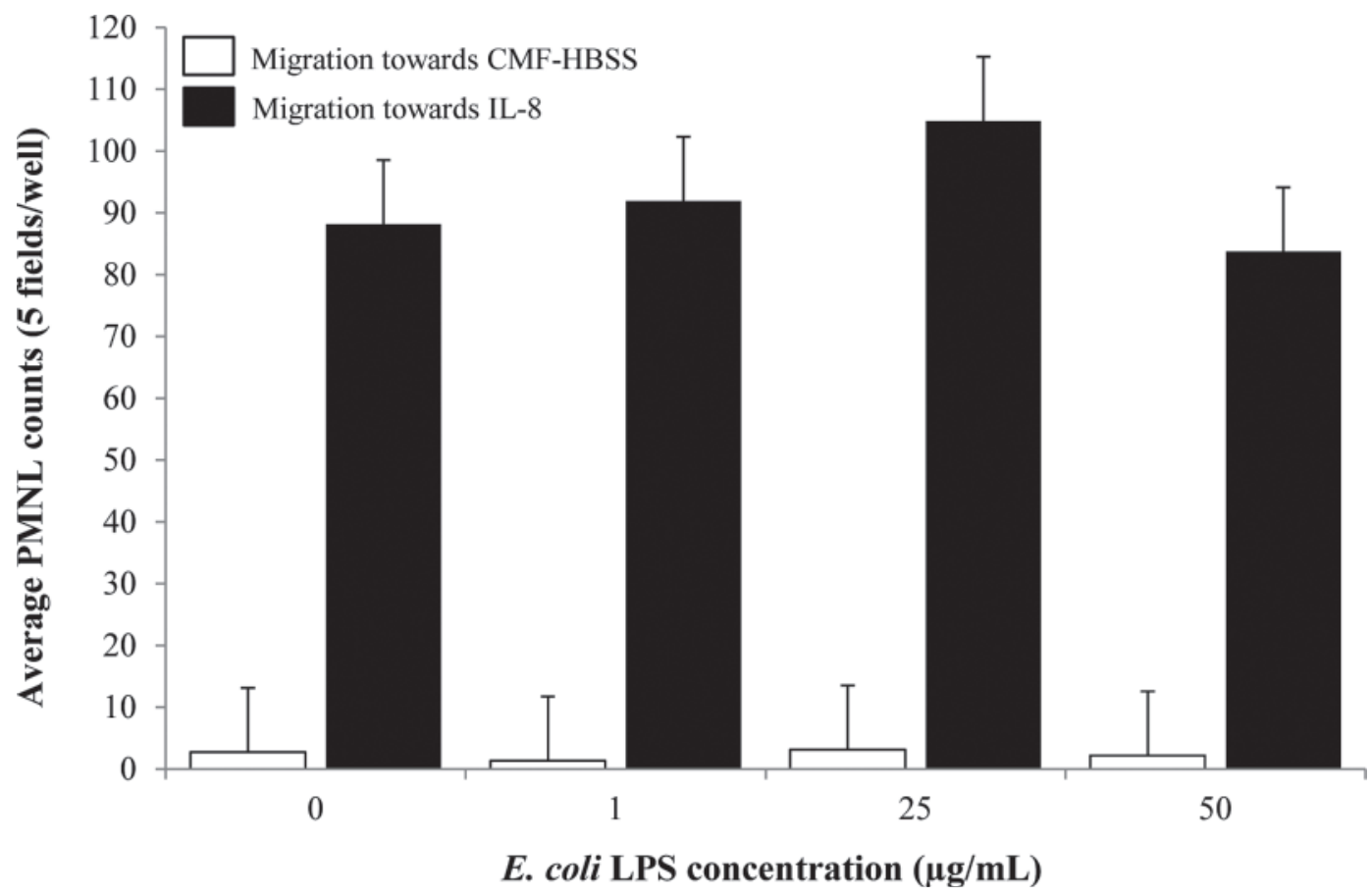

Figure 4. Effect of Escherichia coli LPS on the chemotaxis of bovine PMNL toward the chemoattractant IL-8. The PMNL were collected from the blood of cows in mid lactation $(\mathrm{n}=7)$ and incubated with $0,1,25$, or $50 \mu \mathrm{g} / \mathrm{mL}$ of LPS for 120 min. Bars represent the mean number of migrated neutrophils toward IL- 8 or calcium- and magnesium-free Hanks' balanced salt solution (CMF-HBSS) observed per 5 fields at $1,000 \times$ magnification. The LPS had no effect on the chemotactic ability of PMNL toward IL-8 (LPS effect, $P=0.378$; chemoattractant effect, $P<$ $0.001)$. Error bars represent the standard error of the mean. 


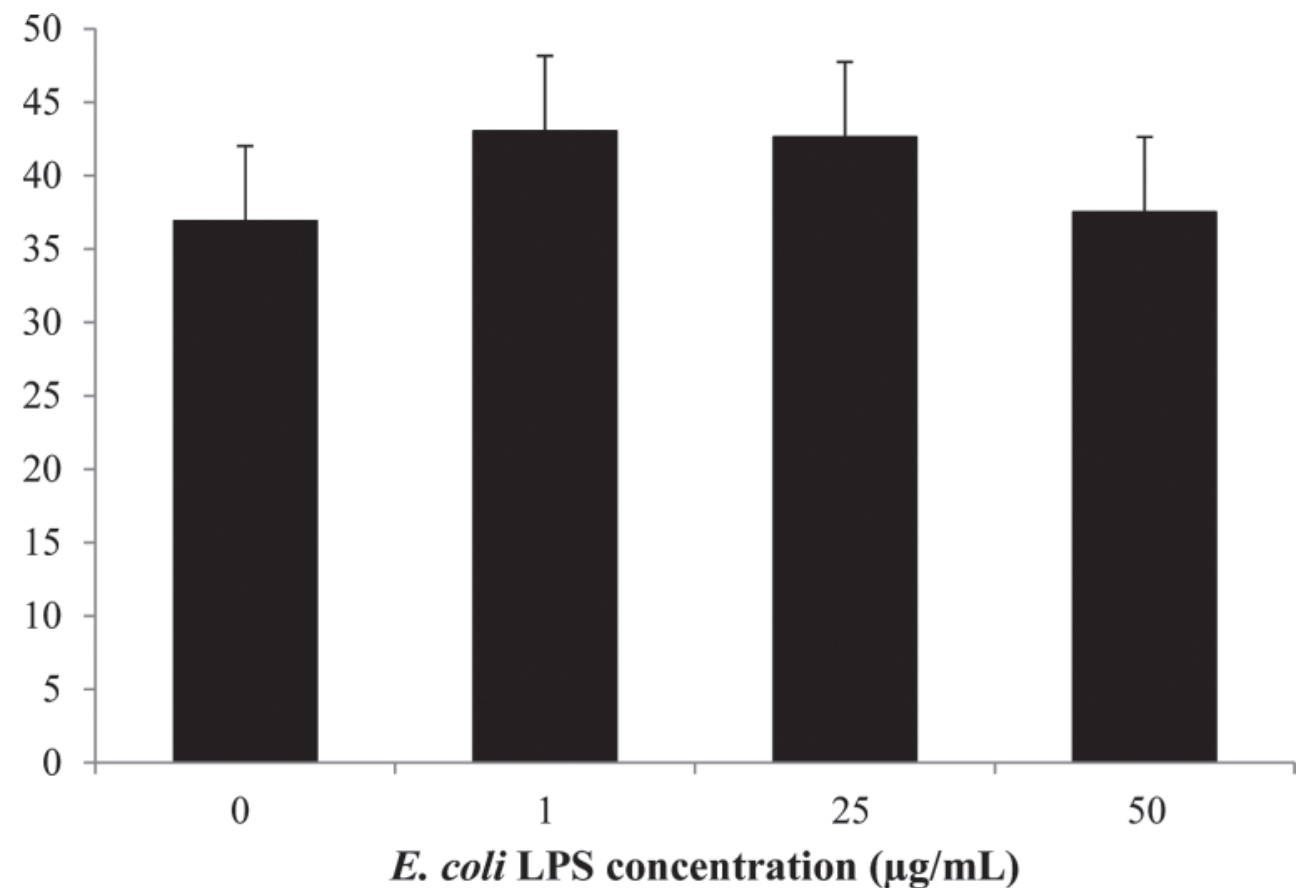

Figure 5. Effect of Escherichia coli LPS on the bactericidal ability of PMNL against Staphylococcus aureus. The PMNL were collected from the blood of cows in mid lactation $(\mathrm{n}=7)$ and incubated with $0,1,25$, or $50 \mu \mathrm{g} / \mathrm{mL}$ of LPS for 120 min. Bars represent the mean percentage of Staph. aureus killed in a 1-h coculture with PMNL determined by dividing the difference in the number of bacteria incubated in the absence and presence of PMNL by the number of bacteria incubated in the absence of PMNL. The LPS had no effect on the bactericidal ability of PMNL against Staph. aureus (LPS effect, $P=0.686$ ). Error bars represent the standard error of the mean.

\section{Neutrophil Gene Expression}

We observed no LPS $\times$ stage of lactation interaction effect on the PMNL expression of $I L-8$ mRNA (Figure $6 \mathrm{~A} ; P=0.599)$. However, gene expression of $I L-8$ was $537 \%$ higher in PMNL incubated with $50 \mu \mathrm{g} / \mathrm{mL}$ relative to $0 \mu \mathrm{g} / \mathrm{mL}$ LPS, independently of stage of lactation (Figure 6B; LPS effect, $P<0.001$ ). In addition, PMNL from mid lactation tended to have $99 \%$ higher $I L-8$ mRNA contents compared with those from early lactation cows (Figure 6C; stage of lactation effect, $P$ $=0.073)$. An LPS $\times$ stage of lactation interaction effect on the expression of TNF was detected, indicating a potent 2,908\% increase in TNF mRNA expression in response to LPS in PMNL from mid lactation but not in PMNL from early lactation cows (Figure 6D; LPS $\times$ stage of lactation effect, $P=0.025)$. Expression of TNF mRNA was $897 \%$ greater in PMNL treated with $50 \mu \mathrm{g} / \mathrm{mL}$ compared with $0 \mu \mathrm{g} / \mathrm{mL}$ LPS, regardless of stage of lactation (Figure 6E; LPS effect, $P<0.001$ ). Expression of TNF mRNA was $482 \%$ higher in PMNL from mid lactation compared with early lactation cows, independently of LPS treatment (Figure 6F; stage of lactation effect, $P=0.020$ ).

An LPS $\times$ stage of lactation interaction effect on the PMNL expression of BPI mRNA was detected (Fig- ure 7A; $P=0.012$ ). Incubation of PMNL with $50 \mu \mathrm{g} /$ mL LPS decreased $(P=0.045)$ the expression of BPI mRNA by $39 \%$ in cells from early lactation cows, in contrast to PMNL from mid lactation cows, in which $B P I$ mRNA expression tended to increase $59 \%$ by LPS $(P=0.082)$.

We observed no LPS $\times$ stage of lactation interaction effect on the PMNL expression of MPO mRNA (Figure $8 \mathrm{~A} ; P=0.632$ ). Addition of LPS did not alter the expression of $M P O$ mRNA in PMNL, regardless of stage of lactation (Figure $8 \mathrm{~B}$; LPS effect, $P=0.188$ ). However, neutrophils from early lactation cows had $634 \%$ higher mRNA contents of MPO compared with mid lactation cows (Figure 8C; stage of lactation effect, $P<0.001)$. We found no LPS $\times$ stage of lactation interaction effect on the expression of PMNL SOD2 mRNA (Figure 8D; $P=0.942$ ). However, contents of SOD2 mRNA were $45 \%$ higher in PMNL incubated with $50 \mu \mathrm{g} / \mathrm{mL}$ compared with $0 \mu \mathrm{g} / \mathrm{mL}$ LPS (Figure $8 \mathrm{E}$; LPS effect, $P=0.034$ ), but were not affected by stage of lactation (Figure 8F; stage of lactation effect $P=0.404)$. There was no LPS by stage of lactation interaction effect on the PMNL mRNA contents of NOX4 (Figure 8G, $P=0.097$ ) and the mRNA expression of $N_{2} 4$ was not affected by LPS (Figure $8 \mathrm{H}, P$ $=0.596$ ) or stage of lactation (Figure $8 \mathrm{I}, P=0.846$ ). 


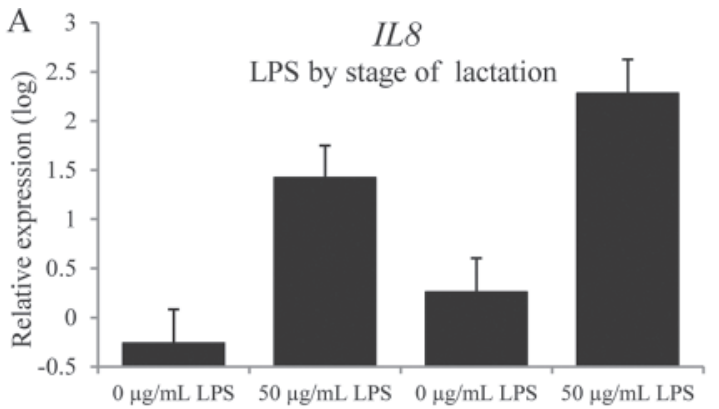

Early lactation

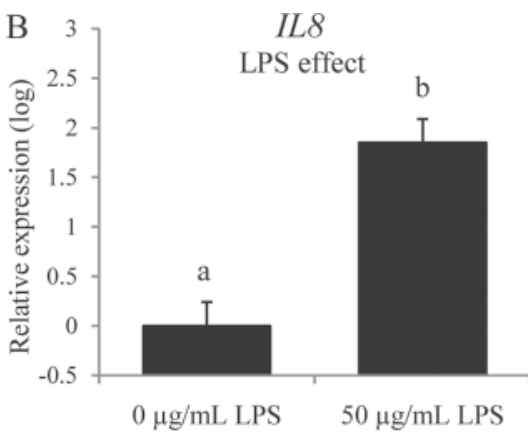

$\mathrm{E}$

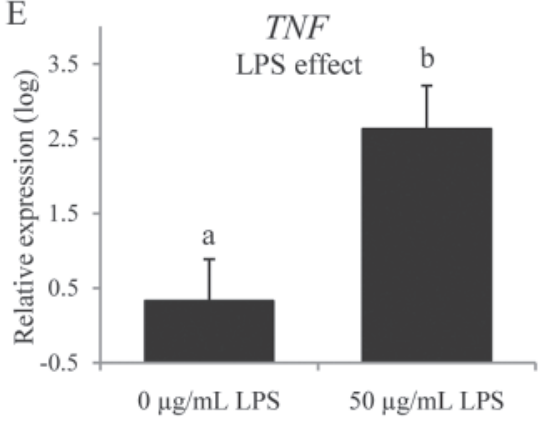

IL8

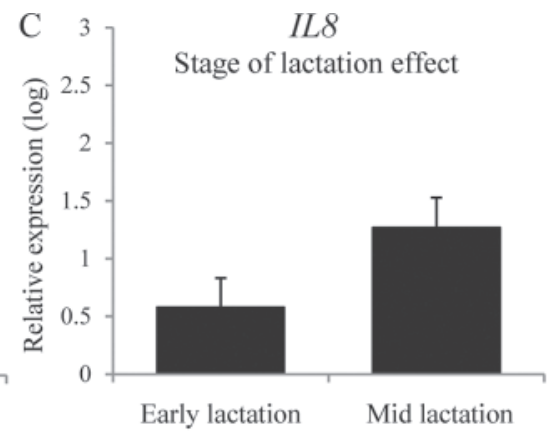

F

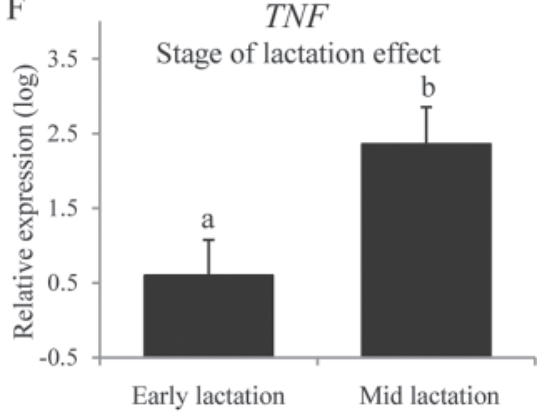

D

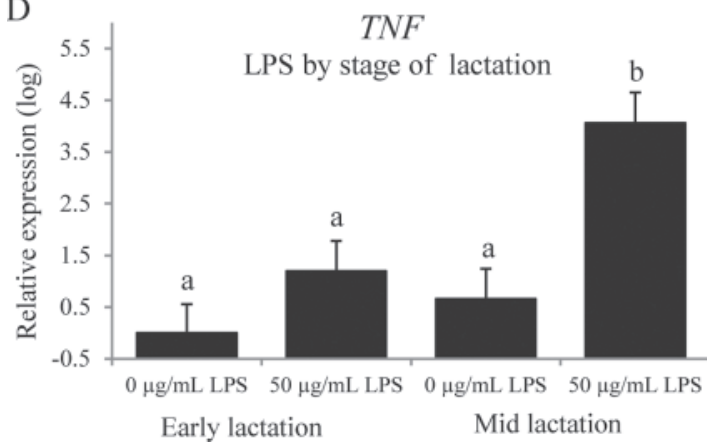

Figure 6. Quantitative real-time PCR analysis of the expression of the inflammatory cytokines IL- 8 and tumor necrosis factor (TNF) in PMNL collected from early lactation $(7 \mathrm{~d}$ after calving, $\mathrm{n}=10)$ and mid lactation $(146 \pm 1.7 \mathrm{~d}$ after calving, $\mathrm{n}=10)$ cows after incubation with 0 or $50 \mu \mathrm{g} / \mathrm{mL}$ of Escherichia coli LPS for $120 \mathrm{~min}$. Bars represent the mean expression (logarithmic scale) of genes normalized by the amount of the endogenous control $\beta$-actin. (A) Effect of interaction of LPS by stage of lactation on $I L-8$ mRNA expression, $P=0.599$; (B) main effect of LPS on $I L-8$ mRNA expression, $P<0.001$; (C) main effect of stage of lactation on $I L-8$ mRNA expression, $P=0.073$; (D) effect of interaction of LPS by stage of lactation on TNF mRNA expression, $P=0.025$; (E) main effect of LPS on TNF mRNA expression, $P<0.001$; (F) main effect of stage of lactation on TNF mRNA expression, $P=0.020$. ${ }^{\mathrm{a}, \mathrm{b}}$ Bars with different letters differ $($ Tukey, $P<0.05)$. Error bars represent the standard error of the mean.

Incubation of PMNL with $50 \mu \mathrm{g} / \mathrm{mL}$ LPS decreased the expression of CYBA mRNA by $49 \%$ in cells from early lactation cows, in contrast to PMNL from mid lactation cows, in which CYBA mRNA expression was increased $158 \%$ by LPS (Figure $8 \mathrm{~J}$; LPS $\times$ stage of lactation effect, $P=0.007)$. We observed no LPS by stage of lactation interaction effect on the PMNL mRNA contents of $H 2 A / 1$ (Figure $9 \mathrm{~A}, P=0.588$ ) or H2B (Figure 9D; $P=0.077$ ). The gene expression of $H 2 A / 1$ and $H 2 B$ mRNA in blood PMNL was not affected by LPS or stage of lactation (Figures 9B, 9C, $9 \mathrm{E}$, and $9 \mathrm{~F}, P>0.20)$.
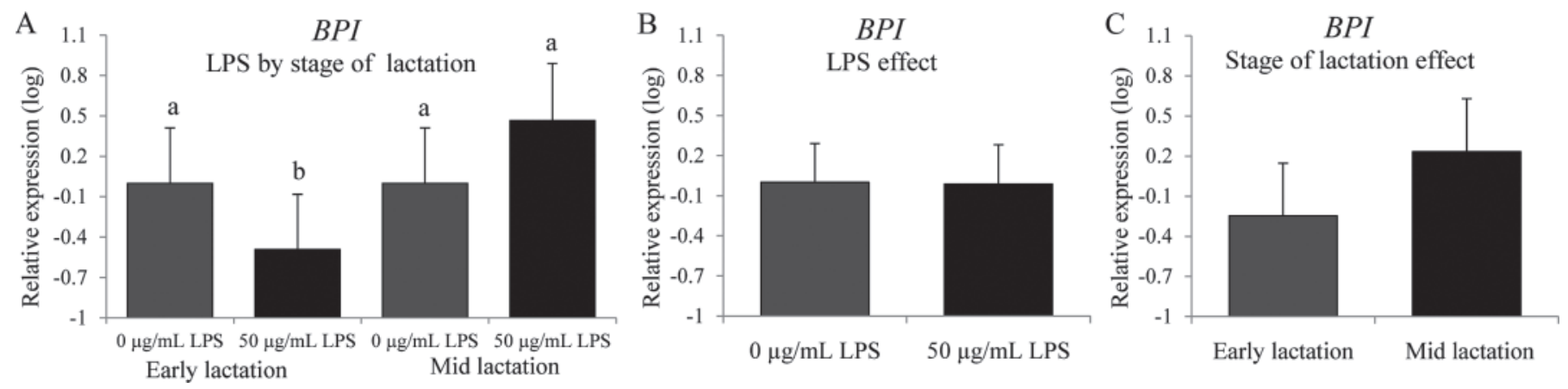

Figure 7. Quantitative real-time PCR analysis of the expression of bactericidal/permeability increasing protein $(B P I)$ in PMNL collected from early lactation $(7 \mathrm{~d}$ after calving, $\mathrm{n}=10)$ and mid lactation $(146 \pm 1.7 \mathrm{~d}$ after calving, $\mathrm{n}=10)$ cows after incubation with 0 or $50 \mu \mathrm{g} /$ $\mathrm{mL}$ of Escherichia coli LPS for $120 \mathrm{~min}$. Bars represent the mean expression (logarithmic scale) of genes normalized by the amount of the endogenous control $\beta$-actin. (A) Effect of interaction of LPS by stage of lactation on BPI mRNA expression, $P=0.012 ;(B)$ main effect of LPS on $B P I$ mRNA expression, $P=0.939$; (C) main effect of stage of lactation on BPI mRNA expression, $P=0.404 .{ }^{\mathrm{a}, \mathrm{b}}$ Bars with different letters differ (orthogonal contrast analysis, $P<0.05$ ). Error bars represent the standard error of the mean. 


\section{DISCUSSION}

In this study, PMNL incubated with 25 and $50 \mu \mathrm{g} /$ $\mathrm{mL}$ of $E$. coli LPS had increased oxidative burst as indicated by 2 independent assays that measure indices of total and intracellular ROS. The total generation of ROS was estimated by a luminol-dependent assay that measures the generation of superoxide $\left(\mathrm{O}_{2}{ }^{-}\right)$, hydroxyl radical $\left(\mathrm{OH}^{-}\right)$, hydrogen peroxide $\left(\mathrm{H}_{2} \mathrm{O}_{2}\right)$, peroxynitrite $\left(\mathrm{ONOO}^{-}\right)$, and hypochlorous acid $(\mathrm{HClO})$, whereas the intracellular generation of ROS was assessed using a CM- $\mathrm{H}_{2}$ DCFDA fluorescence assay that reacts only with ROS that are trapped inside the cell, including $\mathrm{H}_{2} \mathrm{O}_{2}$, nitric oxide (NO), and $\mathrm{ONOO}^{-}$(Rinaldi et al., 2007). Consistent with our findings, an increase in the production of ROS by PMNL in response to LPS in culture media has been observed in neutrophils collected from cows (McClenahan et al., 2000) and humans (Forehand et al., 1989; Aida and Pabst, 1990; Böhmer et al., 1992). McClenahan et al. (2000) incubated blood PMNL collected from healthy cows with either 0 or $10 \mu \mathrm{g} / \mathrm{mL}$ of LPS from $P$. hemolytica for $30 \mathrm{~min}$ and reported an approximately $20 \%$ increase in luminolderived luminescence after activation of PMNL with opsonized zymosan. Increased luminol-dependent ROS generation has been also observed in PMNL collected from the glands of cows after intramammary infusion with Salmonella typhimurium (Sandgren et al., 1992) and E. coli LPS (Mehrzad et al., 2001). Mehrzad et al. (2001) reported that PMNL from the blood and milk of early lactation cows $12 \mathrm{~h}$ after the infusion of $25 \mu \mathrm{g} /$ $\mathrm{mL}$ of $E$. coli LPS into one mammary quarter increased luminol-dependent ROS production compared with that of PMNL collected from non-LPS-infused quarters (Mehrzad et al., 2001). These authors suggested that the increase in ROS production in PMNL collected from blood and LPS-infused quarters could be due to augmented plasma and milk concentrations of TNF- $\alpha$, IL-1, and IL-6, respectively. However, our results and those of McClenahan et al. (2000) indicate that LPS is capable of activating bovine PMNL in a direct manner. Direct LPS activation of PMNL may occur via stimulation of the TLR-4-CD14 receptor complex (Chow et al., 1999) and is likely a calcium-dependent signal transduction process (Forehand et al., 1989).

A novel antimicrobial mechanism termed neutrophil extracellular traps (NET) has been recently described by Brinkmann et al. (2004). Activation of PMNL with PMA, IL-8, or LPS leads to swelling of the nuclei and dissolution of its chromatin to form strands of decondensed DNA. Rupture of intracellular membranes allows mixing of these structures with granule substances, including proteolytic enzymes, antimicrobial proteins, and ROS. Subsequently, these NET are released to the extracellular matrix where they contribute to the killing ability of PMNL by delivering a high concentration of antimicrobial substances and act as a barrier that prevents the microorganisms from spreading (Brinkmann et al., 2004; Brinkmann and Zychlinsky, 2007). In the current study, 25 and $50 \mu \mathrm{g} / \mathrm{mL}$ of LPS enhanced the expression of NET by nonactivated PMNL, whereas LPS had no effect on NET release by PMA-activated neutrophils. It is unclear why $1 \mu \mathrm{g} / \mathrm{mL}$ of LPS had no detectable effect on NET, whereas $0.1 \mu \mathrm{g} / \mathrm{mL}$ of LPS was sufficient to stimulate NET release by human PMNL incubated under similar conditions (Brinkmann et al., 2004). Previous research has shown that bovine PMNL release NET \after activation with the potent kinase C activator PMA (Lippolis et al., 2006b; Revelo and Waldron, 2010) or upon direct contact with E. coli (Grinberg et al., 2008). To our knowledge, this is the first study that demonstrates that bovine PMNL are capable of expressing NET after direct stimulation with LPS.

In this study, LPS had no priming effect on PMNL chemotaxis toward IL-8 as determined in vitro using a modified Boyden micro-chemotaxis chamber. Conversely, human PMNL incubated with $0.01 \mu \mathrm{g} /$ $\mathrm{mL}$ of LPS had approximately a 76 and $55 \%$ decrease in subsequent in vitro chemotaxis in response to the chemoattractants IL-8 and fMLP, respectively (Haslett et al., 1985; Hayashi et al., 2003). Although the physiological relevance of these findings is unclear, Haslett et al. (1985) suggested that reduced chemotaxis capacity by PMNL exposed to LPS is a consequence of increased adhesion properties of the PMNL. In dairy cows, intramammary infusion of LPS induces a massive migration of leukocytes, primarily PMNL, to the mammary gland (Saad and Ostensson, 1990; Bannerman et al., 2003). However, it is likely that this migration of PMNL occurs in response to cytokines released by LPS-stimulated macrophages and mammary epithelial cells because LPS by itself does not attract bovine blood PMNL in vitro (Persson et al., 1993).

A 120-min incubation of blood PMNL with E. coli LPS had no effect on neutrophil killing ability against Staph. aureus. In vivo, intramammary infusion of 100 $\mu \mathrm{g}$ of $E$. coli LPS into the glands of cows experimentally infected with Staph. aureus elevated their inflammatory response but had no effect on bacterial clearance compared with infected glands infused with PBS (Kauf et al., 2007). The reason why E. coli LPS did not increase killing of Staph. aureus in the current study and that of Kauf et al. (2007) is unclear, but could be explained by the different mechanisms used by the PMNL to recognize and respond to gram-positive and gram-negative bacteria. For instance, host responses to E. coli are characterized by an acute inflammatory response, 

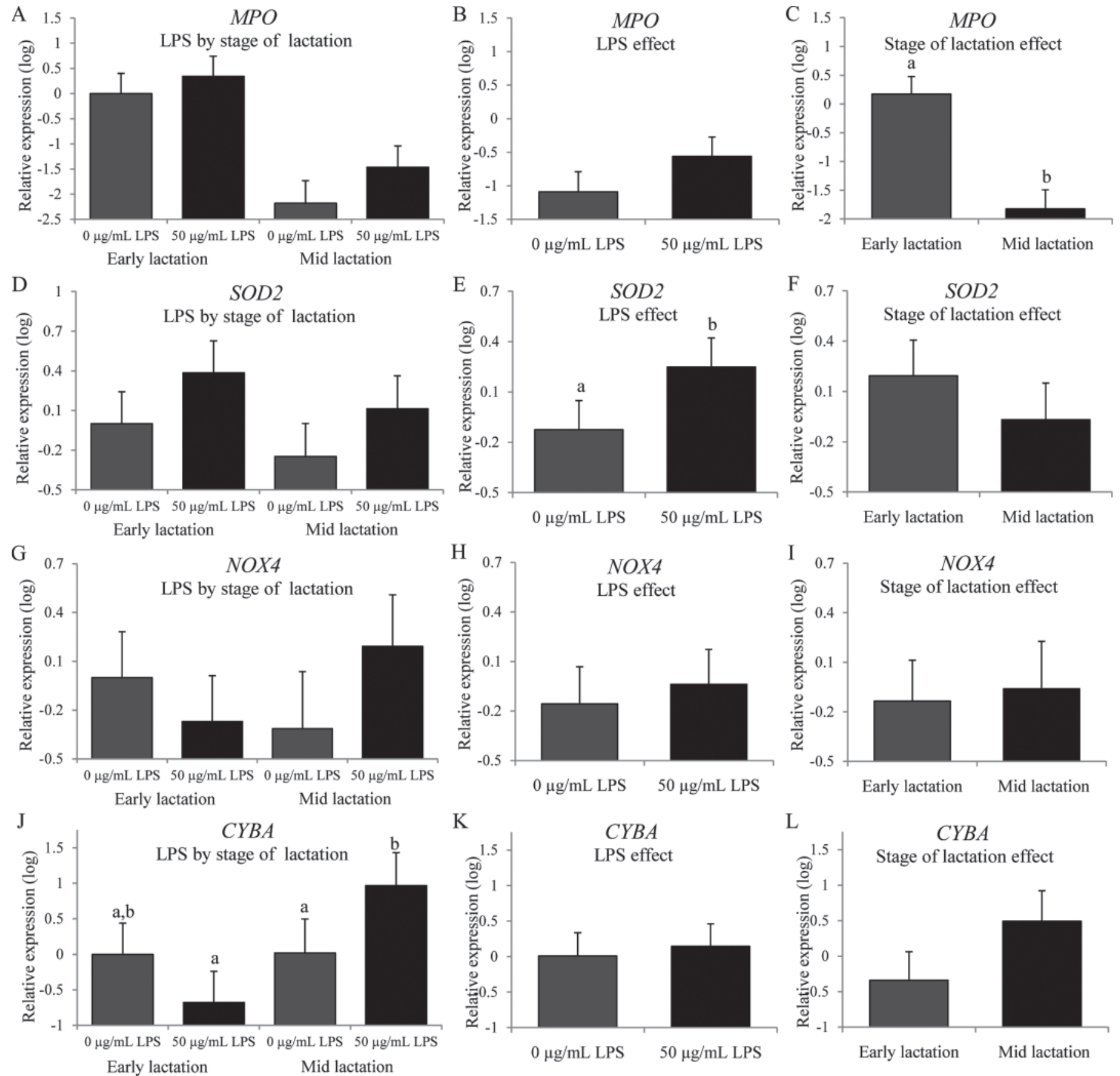

Figure 8. Quantitative real-time PCR analysis of the expression of the proteins involved in the production of reactive oxygen species myeloperoxidase (MPO), superoxide dismutase 2 (SOD2), NADPH oxidase 4 (NOX4), and cytochrome $b$-245, $\alpha$ polypeptide (CYBA) in PMNL collected from early lactation $(7 \mathrm{~d}$ after calving, $\mathrm{n}=10)$ and mid lactation $(146 \pm 1.7 \mathrm{~d}$ after calving, $\mathrm{n}=10)$ cows after incubation with 0 or $50 \mu \mathrm{g} / \mathrm{mL}$ of Escherichia coli LPS for $120 \mathrm{~min}$. Bars represent the mean expression (logarithmic scale) of genes normalized by the amount of the endogenous control $\beta$-actin. (A) Effect of interaction of LPS by stage of lactation on $M P O$ mRNA expression, $P=0.632$; (B) main effect of LPS on $M P O$ mRNA expression, $P=0.188$; (C) main effect of stage of lactation on $M P O$ mRNA expression, $P<0.001$; (D) effect of interaction of LPS by stage of lactation on SOD2 mRNA expression, $P=0.942$; (E) main effect of LPS on SOD2 mRNA expression, $P=0.038 ;(\mathrm{F})$ main effect of stage of lactation on SOD2 mRNA expression, $P=0.404 ;(\mathrm{G})$ effect of interaction of LPS by stage of lactation on $N O X 4$ mRNA expression, $P=0.097 ;(\mathrm{H})$ main effect of LPS on $N O X_{4}$ mRNA expression, $P=0.596$; (I) main effect of stage of lactation on $N O X 4$ mRNA expression, $P$ $=0.846 ;(\mathrm{J})$ effect of interaction of LPS by stage of lactation on $C Y B A$ mRNA expression, $P=0.007 ;(\mathrm{K})$ main effect of LPS on $C Y B A$ mRNA expression, $P=0.619$; (L) main effect of stage of lactation on $C Y B A$ mRNA expression, $P=0.173$. ${ }^{a, b}$ Bars with different letters differ (Tukey, $P<0.05)$. Error bars represent the standard error of the mean. 
A

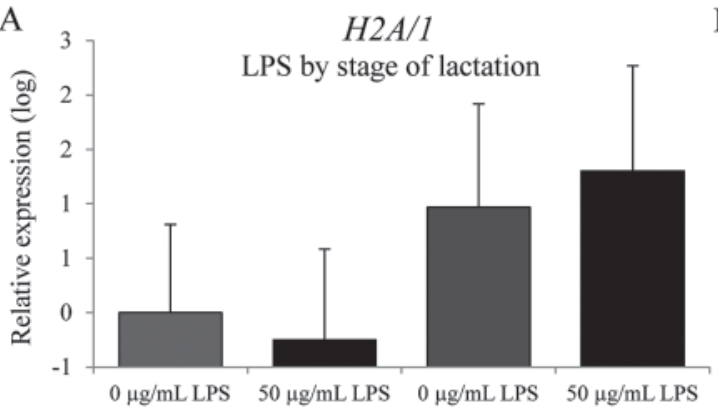

Early lactation

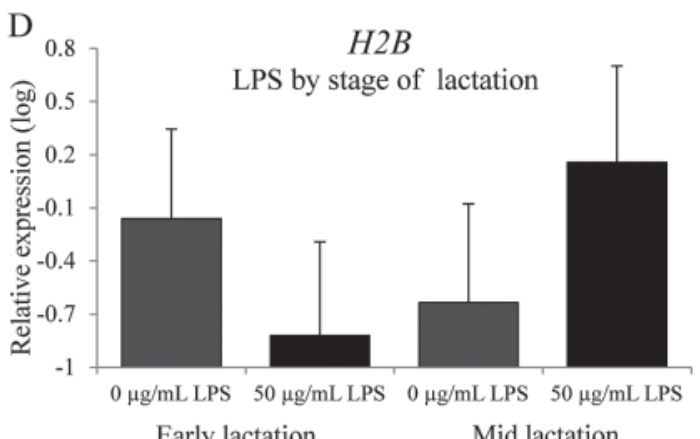

B

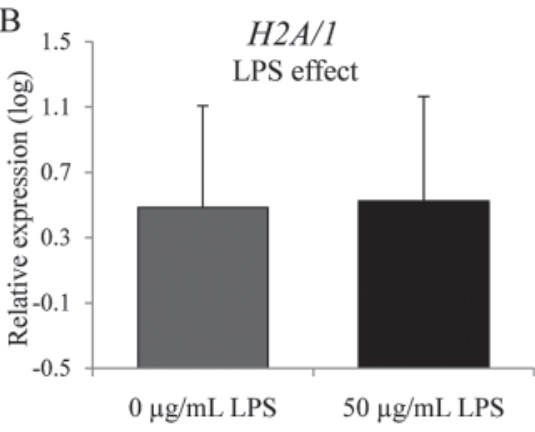

E

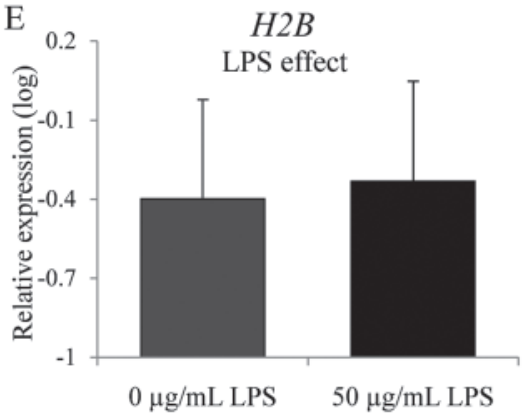

C

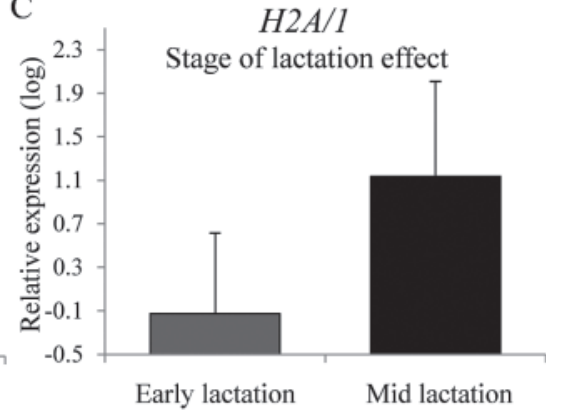

F

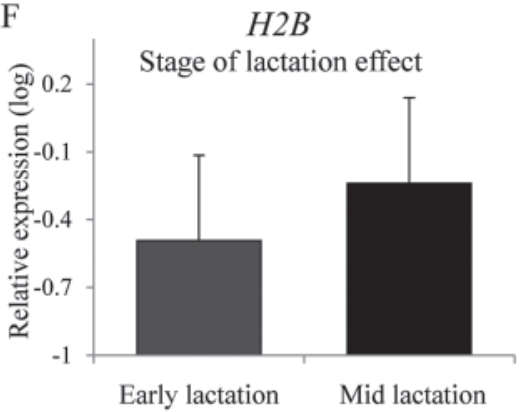

Figure 9. Quantitative real-time PCR analysis of the mRNA expression of the histones H2A/1 and H2B, structural components of neutrophil (PMNL) extracellular traps. PMNL were collected from early lactation ( $7 \mathrm{~d}$ after calving, $\mathrm{n}=10)$ and mid lactation $(146 \pm 1.7 \mathrm{~d}$ after calving, $\mathrm{n}$ $=10$ ) cows and then incubated with 0 or $50 \mu \mathrm{g} / \mathrm{mL}$ of Escherichia coli LPS for 120 min. Bars represent the mean expression (logarithmic scale) of genes normalized by the amount of the endogenous control $\beta$-actin. (A) Effect of interaction of LPS by stage of lactation on $H 2 A / 1$ mRNA expression, $P=0.588$; (B) main effect of LPS on $H 2 A / 1$ mRNA expression, $P=0.939$; (C) main effect of stage of lactation on $H 2 A / 1$ mRNA expression, $P=0.289$; (D) effect of interaction of LPS by stage of lactation on $H 2 B$ mRNA expression, $P=0.077$; (E) main effect of LPS on H2B mRNA expression, $P=0.863$; $(\mathrm{F})$ main effect of stage of lactation on $H 2 B$ mRNA expression, $P=0.706$. Addition of LPS and stage of lactation had no effect on the expression of $H 2 A / 1$ and $H 2 B$ mRNA by bovine PMNL. Error bars represent the standard error of the mean.

whereas infections with Staph. aureus result in a more chronic state of activation (Bannerman et al., 2004). In addition, cells of the innate immune system can discern between highly conserved motifs known as pathogenassociated molecular patterns. These patterns, such as peptidoglycan, are present in most bacteria, whereas LPS and lipoteichoic acid (LTA) are found only in gram-negative and gram-positive bacteria, respectively (Aderem and Ulevitch, 2000). Distinct TLR are used by the innate immune system to discriminate between gram-positive and gram-negative bacteria. For example, TLR-4 expressed by bovine PMNL (and other cell types) recognizes LPS in conjunction with the accessory molecules LBP, CD14, and MD-2 (De Schepper et al., 2008; Worku and Morris, 2009). In contrast, TLR-2 mediates the recognition of a wide variety of products of gram-positive bacteria such as LTA (Aderem and Ulevitch, 2000). Although TLR-2 has been found to be expressed by bovine monocytes, monocyte-derived macrophages, and dendritic cells (Kwong et al., 2011), the role of TLR-2 in the recognition of gram-positive bacteria by the bovine PMNL remains to be elucidated.
Incubation of PMNL with LPS enhanced the expression of genes encoding for IL- 8 and TNF- $\alpha$, cytokines involved in the inflammatory response. The PMNL incubated with $50 \mu \mathrm{g} / \mathrm{mL}$ of LPS showed a dramatic increase in the mRNA expression of $I L-8$ independent of stage of lactation, although $I L-8$ mRNA levels tended to be higher in PMNL collected from mid lactation compared with early lactation cows (day of lactation effect, $P=0.073$ ). Our results are supported by other research indicating that $E$. coli LPS induces the expression of $I L-8$ mRNA by bovine PMNL, as determined by qualitative (Worku and Morris, 2009) and quantitative real-time PCR (Yu et al., 2010). Yu et al. (2010) incubated bovine PMNL with 0, 0.001, 0.01, 0.1 and $1 \mu \mathrm{g} /$ $\mathrm{mL}$ LPS for $6 \mathrm{~h}$ and reported that only those PMNL incubated with $1 \mu \mathrm{g} / \mathrm{mL}$ had an approximately $1,700 \%$ increase in the levels of $I L-8 \mathrm{mRNA}$ compared with controls. The magnitude of increase in $I L-8 \mathrm{mRNA}$ expression after PMNL incubation with LPS was lower in our study (537\%), despite the use of a higher dose $(50 \mu \mathrm{g} / \mathrm{mL})$. Different outcomes between these studies may be explained by the shorter incubation time 
and the lack of serum components in the culture media used in our experiments. Incubation with LPS greatly augmented the mRNA expression of TNF in PMNL isolated from mid lactation cows, but had no effect in PMNL from early lactation cows. Lipopolysaccharide has been shown to increase the mRNA levels of $T N F$ in human (Laudanna et al., 1994) and bovine (Worku and Morris, 2009) PMNL. Although only low levels of TNF transcripts were detected, Worku and Morris (2009) reported that incubation of PMNL from mid lactation cows with $0.1 \mu \mathrm{g}$ of E. coli LPS for $30 \mathrm{~min}$ induced the expression of TNF mRNA. Importantly, the increase in $I L-8$ and TNF mRNA expression observed in these studies is consistent with the secretion of these cytokines by bovine PMNL after stimulation by LPS (Sohn et al. 2007b). In our study, expression of TNF mRNA in PMNL from mid lactation was approximately $482 \%$ greater than in PMNL from early lactation cows. In contrast, Sordillo et al. (1995) reported that LPS-stimulated peripheral blood mononuclear cells collected from periparturient cows produced more TNF- $\alpha$ than those from mid lactation cows. However, these authors suggested that this increase could be explained by a higher percentage of monocytes present in the mononuclear-enriched cell preparations from periparturient cows, rather than augmented production per cell. Moyes et al. (2010) collected PMNL from the blood of mid lactation cows fed for ad libitum intake or restricted to $60 \%$ of their requirements and reported that the PMNL of feed-restricted cows showed a decrease in the contents of TNF mRNA after intramammary infusion of Streptococcus uberis. These researchers suggested that experimentally induced negative energy balance, mimicking that of periparturient cows, might be involved in the reduced immune response observed during this period. Together, these findings suggest that PMNL have a supportive role during the innate immune response involving the production of cytokines. In turn, these cytokines may act in an endocrine, paracrine, or autocrine manner to initiate the inflammatory reaction against the invading pathogen. That the expression of $I L-8$ and $T N F$ mRNA by PMNL was lower in early lactation compared with mid lactation may indicate that reduced capacity of PMNL to produce these cytokines may contribute to altered immune function observed during the periparturient period (Detilleux et al., 1995).

Bactericidal/permeability-increasing protein, a glycoprotein stored in the azurophilic granules of PMNL, has several roles during the inflammatory response, including LPS binding, specific bactericidal activity for gram-negative bacteria, and activation of complement for opsonization of microorganisms before their phagocytosis by PMNL (Nishimura et al., 2001). In the present study, the effect of LPS by stage of lactation on $B P I$ mRNA expression suggests that LPS decreases the expression of $B P I$ in PMNL from early lactation cows but increases its expression in PMNL from mid lactation cows, relative to nonstimulated neutrophils from cows in the same stage of lactation. In nonstimulated PMNL, protein expression of BPI in the membrane of bovine PMNL has been reported to be unchanged between periparturient and mid lactation cows (Lippolis et al., 2006a). Our results suggest that PMNL may have reduced capacity to produce BPI in response to stimuli during early lactation.

We investigated the effect of LPS and stage of lactation on genes encoding proteins that are involved in the production of ROS by PMNL such as MPO, SOD2, NOX4, and CYBA. Upon activation of PMNL, the generation of the oxidative burst is initiated by the NADPH oxidase enzyme complex that produces large amounts of antimicrobial ROS such as $\mathrm{O}_{2}{ }^{-}$and $\mathrm{H}_{2} \mathrm{O}_{2}$ (Paape et al., 2003). The enzyme system NADPH oxidase is formed by several membrane subunits including the catalytic subunit $N_{4} X_{4}$ and the cytochrome $b$-light chain subunit $C Y B A$ also known as p22-phox (Sheppard et al., 2005). Furthermore, $\mathrm{O}_{2}{ }^{-}$produced by NADPH oxidase can be converted by the manganesecontaining mitochondrial protein SOD2 to $\mathrm{H}_{2} \mathrm{O}_{2}$ and $\mathrm{O}_{2}$. These $\mathrm{H}_{2} \mathrm{O}_{2}$ molecules can either form potent antimicrobial agents such as free hydroxyl radicals or react with chloride ions to produce hypochlorous acid in a reaction catalyzed by MPO (Holley et al., 2010). In our study, LPS increased the mRNA content of SOD2 in PMNL by $45 \%$, regardless of stage of lactation. In humans, incubation of PMNL with $0.1 \mu \mathrm{g} / \mathrm{mL}$ of LPS increased the expression of SOD2 in PMNL collected from healthy donors whereas SOD2 in patients with chronic kidney disease was diminished by LPS (Olsson et al., 2011). Another interesting finding in the current study was the decreased $C Y B A$ mRNA contents of LPS-stimulated PMNL collected from early lactation compared with those from mid lactation cows. Both subunits of flavocytochrome b, CYBA (p22-phox) and $C Y B B$ (gp91-phox) have been cloned and sequenced in bovine PMNL (Davis et al., 1998). To our knowledge, this is the first report of a reduced expression of $C Y B A$ mRNA in LPS-stimulated PMNL from early lactation cows. In humans, a missense mutation in $C Y B A$ results in a nonfunctional cytochrome $b$ in patients with chronic granulomatous disease, a condition characterized by a defect in phagocyte production of $\mathrm{O}_{2}^{-}$(Dinauer et al., 1991). Perhaps the lower expression of $C Y B A$ by bovine PMNL in early lactation contributes to the reduced capacity of PMNL to produce ROS during this period. Addition of LPS had no effect on the mRNA expression of $M P O$ and $N_{2} X_{4}$ by bovine PMNL. Thus, 
the increase in the production of ROS by PMNL after stimulation with LPS observed in this study may be mediated in part by a higher expression of SOD2 and $C Y B A$ mRNA. Furthermore, PMNL from early lactation had higher mRNA contents of $M P O$ than PMNL from mid lactation cows. Conversely, bovine PMNL MPO protein expression (Lippolis et al., 2006a) and activity (Cai et al., 1994) have been reported to be lower during the periparturient period, consistent with the reduction in ROS generation observed during this period. Although the reason for the higher $M P O$ mRNA expression in early lactation observed in our study is unclear, an increase in mRNA contents for this gene might not result in augmented protein expression or activity. Previous findings from our laboratory (Revelo and Waldron, 2010) indicate that the generation of total, intracellular, and extracellular ROS by PMNL is decreased in early lactation compared with mid lactation cows. As an example, some mRNA can be retained in the nucleus of cells, resulting in overestimation of their levels when compared with the expression of their corresponding protein (Gry et al., 2009).

Expression of H2A/1 and H2B mRNA was not affected by LPS treatment or stage of lactation. Lippolis et al. (2006a) reported that the protein content of $\mathrm{H} 2 \mathrm{~A} / 1$ in the cytosol of PMNL from periparturient cows was not different compared with PMNL from mid lactation cows. However, the membrane of PMNL from early lactation cows had lower protein levels of $\mathrm{H} 2 \mathrm{~A} / 1$ but higher levels of H2B.f and H2B.e, compared with that of mid lactation animals (Lippolis et al., 2006a). These authors suggested that these differences in histone expression between nuclear fractions are related to the ability of the PMNL to rearrange these histones at the membrane. Although the role of histones in the context of NET release is not fully understood, histones may be involved during NET killing of microbes by 2 mechanisms. First, histone posttranscriptional modifications are linked to changes of chromatin during NET formation, and second, histones have independent microbial binding and antimicrobial properties that contribute to the killing capacity of NETs (Papayannopoulos and Zychlinsky, 2009). The role of histones in NET microbial killing by bovine PMNL and their effect on the immune response of periparturient dairy cows warrants further investigation.

\section{CONCLUSIONS}

Our findings support that E. coli LPS has a direct effect on bovine PMNL function via stimulation of their total and intracellular generation of ROS and expression of NET. In contrast, LPS did not alter PMNL chemotaxis toward IL-8 or their antimicrobial capacity against Staph. aureus. The PMNL incubated with 50 $\mu \mathrm{g} / \mathrm{mL}$ LPS had increased mRNA expression of the cytokines IL-8 and TNF, which are involved in the inflammatory response, and the enzyme SOD2, which is involved in the formation of $\mathrm{H}_{2} \mathrm{O}_{2}$ from $\mathrm{O}_{2}{ }^{-}$. Together, these results indicate a stimulatory effect of LPS toward enhanced bovine neutrophil activity and cytokine production. It is unclear if this increased PMNL activity after exposure to LPS would be beneficial or detrimental in vivo. Regardless of LPS treatment, PMNL collected from early lactation cows had reduced contents of $I L-8$ but increased $M P O \mathrm{mRNA}$, compared with that of mid lactation cows. After incubation of PMNL with LPS, the mRNA expression of $C Y B A$, a component of the NADPH oxidase complex, was decreased in PMNL collected from early lactation compared with PMNL from mid lactation cows. The lower expression of genes encoding for cytokines and enzymes involved in ROS production by PMNL isolated from the blood of early lactation cows may contribute to the altered PMNL function observed during the periparturient period.

\section{REFERENCES}

Aderem, A., and R. J. Ulevitch. 2000. Toll-like receptors in the induction of the innate immune response. Nature 406:782-787.

Aida, Y., and M. J. Pabst. 1990. Priming of neutrophils by lipopolysaccharide for enhanced release of superoxide. Requirement for plasma but not for tumor necrosis factor-alpha. J. Immunol. 145:3017-3025.

Anri, A. 1989. Detection of endotoxin in affected milk from cows with coliform mastitis. Nippon Juigaku Zasshi 51:847-848.

Asehnoune, K., D. Strassheim, S. Mitra, J. Y. Kim, and E. Abraham. 2004. Involvement of reactive oxygen species in Toll-like receptor 4-dependent activation of NF-кB. J. Immunol. 172:2522-2529.

Bannerman, D. D., M. J. Paape, W. R. Hare, and E. J. Sohn. 2003. Increased levels of LPS-binding protein in bovine blood and milk following bacterial lipopolysaccharide challenge. J. Dairy Sci. $86: 3128-3137$.

Bannerman, D. D., M. J. Paape, J. W. Lee, X. Zhao, J. C. Hope, and P. Rainard. 2004. Escherichia coli and Staphylococcus aureus elicit differential innate immune responses following intramammary infection. Clin. Diagn. Lab. Immunol. 11:463-472.

Böhmer, R. H., L. S. Trinkle, and J. L. Staneck. 1992. Dose effects of LPS on neutrophils in a whole blood flow cytometric assay of phagocytosis and oxidative burst. Cytometry 13:525-531.

Brinkmann, V., U. Reichard, C. Goosmann, B. Fauler, Y. Uhlemann, D. S. Weiss, Y. Weinrauch, and A. Zychlinsky. 2004. Neutrophil extracellular traps kill bacteria. Science 303:1532-1535.

Brinkmann, V., and A. Zychlinsky. 2007. Beneficial suicide: Why neutrophils die to make NET. Nat. Rev. Microbiol. 5:577-582.

Burvenich, C., D. D. Bannerman, J. D. Lippolis, L. Peelman, B. J. Nonnecke, M. E. Kehrli Jr., and M. J. Paape. 2007. Cumulative physiological events influence the inflammatory response of the bovine udder to Escherichia coli infections during the transition period. J. Dairy Sci. 90(E. Suppl.):E39-E54.

Burvenich, C., V. Van Merris, J. Mehrzad, A. Diez-Fraile, and L. Duchateau. 2003. Severity of $E$. coli mastitis is mainly determined by cow factors. Vet. Res. 34:521-564.

Cai, T. Q., P. G. Weston, L. A. Lund, B. Brodie, D. J. McKenna, and W. C. Wagner. 1994. Association between neutrophil functions and periparturient disorders in cows. Am. J. Vet. Res. 55:934-943. 
Chow, J. C., D. W. Young, D. T. Golenbock, W. J. Christ, and F. Gusovsky. 1999. Toll-like receptor-4 mediates lipopolysaccharideinduced signal transduction. J. Biol. Chem. 274:10689-10692.

Davis, A. R., P. L. Mascolo, P. L. Bunger, K. M. Sipes, and M. T. Quinn. 1998. Cloning and sequencing of the bovine flavocytochrome b subunit proteins, gp91-phox and p22-phox: Comparison with other known flavocytochrome b sequences. J. Leukoc. Biol. 64:114-123.

De Schepper, S., A. De Ketelaere, D. D. Bannerman, M. J. Paape, L. Peelman, and C. Burvenich. 2008. The toll-like receptor-4 (TLR4) pathway and its possible role in the pathogenesis of Escherichia coli mastitis in dairy cattle. Vet. Res. 39:05.

Detilleux, J. C., M. E. Kehrli Jr., J. R. Stabel, A. E. Freeman, and D. H. Kelley. 1995. Study of immunological dysfunction in periparturient Holstein cattle selected for high and average milk production. Vet. Immunol. Immunopathol. 44:251-267.

Dinauer, M. C., E. A. Pierce, R. W. Erickson, T. J. Muhlebach, H. Messner, S. H. Orkin, R. A. Seger, and J. T. Curnutte. 1991. Point mutation in the cytoplasmic domain of the neutrophil p22-phox cytochrome b subunit is associated with a nonfunctional NADPH oxidase and chronic granulomatous disease. Proc. Natl. Acad. Sci. USA 88:11231-11235.

Dosogne, H., F. Vangroenweghe, B. Barrio, P. Rainard, and C. Burvenich. 2001. Decreased number and bactericidal activity against Staphylococcus aureus of the resident cells in milk of dairy cows during early lactation. J. Dairy Res. 68:539-549.

Forehand, J. R., M. J. Pabst, W. A. Phillips, and R. B. Johnston Jr.. 1989. Lipopolysaccharide priming of human neutrophils for an enhanced respiratory burst. Role of intracellular free calcium. J. Clin. Invest. 83:74-83.

Freitas, M., G. Porto, J. L. Lima, and E. Fernandes. 2009. Optimization of experimental settings for the analysis of human neutrophils oxidative burst in vitro. Talanta 78:1476-1483.

Grinberg, N., S. Elazar, L. Rosenshine, and N. Y. Shpigel. 2008. $\beta$-Hydroxybutyrate abrogates formation of bovine neutrophil extracellular traps and bactericidal activity against mammary pathogenic Escherichia coli. Infect. Immun. 76:2802-2807.

Gry, M., R. Rimini, S. Strömberg, A. Asplund, F. Pontén, M. Uhlén, and P. Nilsson. 2009. Correlations between RNA and protein expression profiles in 23 human cell lines. BMC Genomics 10:365.

Hakogi, E., H. Tamura, S. Tanaka, A. Kohata, Y. Shimada, and K. Tabuchi. 1989. Endotoxin levels in milk and plasma of mastitisaffected cows measured with a chromogenic limulus test. Vet. Microbiol. 20:267-274.

Haslett, C., L. A. Guthrie, M. M. Kopaniak, R. B. Johnston Jr., and P. M. Henson. 1985. Modulation of multiple neutrophil functions by preparative methods or trace concentrations of bacterial lipopolysaccharide. Am. J. Pathol. 119:101-110.

Hayashi, F., T. K. Means, and A. D. Luster. 2003. Toll-like receptors stimulate human neutrophil function. Blood 102:2660-2669.

Hogan, J. S., and K. L. Smith. 2003. Coliform mastitis. Vet. Res. 34:507-519.

Holley, A. K., S. K. Dhar, and D. K. St Clair. 2010. Manganese superoxide dismutase versus p53: The mitochondrial center. Ann. N. Y. Acad. Sci. 1201:72-78

Ibeagha-Awemu, E. M., J. W. Lee, A. E. Ibeagha, D. D. Bannerman, M. J. Paape, and X. Zhao. 2008. Bacterial lipopolysaccharide induces increased expression of toll-like receptor (TLR) 4 and downstream TLR signaling molecules in bovine mammary epithelial cells. Vet. Res. 39:11.

Kaps, M., and W. Lamberson. 2004. Biostatistics for Animal Science. CAB International, Wallingford, UK.

Kauf, A. C., B. T. Vinyard, and D. D. Bannerman. 2007. Effect of intramammary infusion of bacterial lipopolysaccharide on experimentally induced Staphylococcus aureus intramammary infection. Res. Vet. Sci. 82:39-46.

Kehrli, M. E. Jr., and J. P. Goff. 1989. Periparturient hypocalcemia in cows: Effects on peripheral blood neutrophil and lymphocyte function. J. Dairy Sci. 72:1188-1196.

Kwong, L. S., R. Parsons, R. Patterson, T. J. Coffey, L. Thonur, J. S. Chang, G. Russell, D. Haig, D. Werling, and J. C. Hope. 2011.
Characterisation of antibodies to bovine toll-like receptor (TLR)-2 and cross-reactivity with ovine TLR2. Vet. Immunol. Immunopathol. 139:313-318.

Laudanna, C., G. Constantin, P. Baron, E. Scarpini, G. Scarlato, G. Cabrini, C. Dechecchi, F. Rossi, M. A. Cassatella, and G. Berton. 1994. Sulfatides trigger increase of cytosolic free calcium and enhanced expression of tumor necrosis factor-alpha and interleukin-8 mRNA in human neutrophils. Evidence for a role of L-selectin as a signaling molecule. J. Biol. Chem. 269:4021-4026.

Lippolis, J. D., B. D. Peterson-Burch, and T. A. Reinhardt. 2006a. Differential expression analysis of proteins from neutrophils in the periparturient period and neutrophils from dexamethasone-treated dairy cows. Vet. Immunol. Immunopathol. 111:149-164.

Lippolis, J. D., T. A. Reinhardt, J. P. Goff, and R. L. Horst. 2006b. Neutrophil extracellular trap formation by bovine neutrophils is not inhibited by milk. Vet. Immunol. Immunopathol. 113:248255 .

Littell, R. C., P. R. Henry, and C. B. Ammerman. 1998. Statistical analysis of repeated measures data using SAS procedures. J. Anim. Sci. 76:1216-1231.

Livak, K. J., and T. D. Schmittgen. 2001. Analysis of relative gene expression data using real-time quantitative PCR and the 2(-Delta Delta $\mathrm{C}(\mathrm{T})$ ) method. Methods 25:402-408.

McClenahan, D., J. Fagliari, O. Evanson, and D. Weiss. 2000. Role of inflammatory mediators in priming, activation, and deformability of bovine neutrophils. Am. J. Vet. Res. 61:492-498.

Mehrzad, J., H. Dosogne, E. Meyer, and C. Burvenich. 2001. Local and systemic effects of endotoxin mastitis on the chemiluminescence of milk and blood neutrophils in dairy cows. Vet. Res. 32:131-144.

Moyes, K. M., J. K. Drackley, D. E. Morin, and J. J. Loor. 2010. Greater expression of TLR2, TLR4, and IL6 due to negative energy balance is associated with lower expression of HLA-DRA and HLA-A in bovine blood neutrophils after intramammary mastitis challenge with Streptococcus uberis. Funct. Integr. Genomics 10:53-61.

NCBI (National Center for Biotechnology Information). 2010. BLAST assembled RefSeq genomes. Accessed Oct. 2010. http://blast.ncbi. nlm.nih.gov/.

Nishimura, H., A. Gogami, Y. Miyagawa, A. Nanbo, Y. Murakami, T. Baba, and S. Nagasawa. 2001. Bactericidal/permeability-increasing protein promotes complement activation for neutrophil-mediated phagocytosis on bacterial surface. Immunology 103:519-525.

Olsson, J., T. A. Jacobson, J. M. Paulsson, E. Dadfar, A. Moshfegh, S. H. Jacobson, and J. Lundahl. 2011. Expression of neutrophil SOD2 is reduced after lipopolysaccharide stimulation: A potential cause of neutrophil dysfunction in chronic kidney disease. Nephrol. Dial. Transplant. 26:2195-2201. http://dx.doi.org/10.1093/ndt/gfq673.

Paape, M. J., D. D. Bannerman, X. Zhao, and J. W. Lee. 2003. The bovine neutrophil: Structure and function in blood and milk. Vet. Res. 34:597-627.

Paape, M. J., J. Mehrzad, X. Zhao, J. Detilleux, and C. Burvenich. 2002. Defense of the bovine mammary gland by polymorphonuclear neutrophil leukocytes. J. Mammary Gland Biol. Neoplasia $7: 109-121$

Papayannopoulos, V., and A. Zychlinsky. 2009. NET: A new strategy for using old weapons. Trends Immunol. 11:513-521.

Persson, K., I. Larsson, and C. Hallén Sandgren. 1993. Effects of certain inflammatory mediators on bovine neutrophil migration in vivo and in vitro. Vet. Immunol. Immunopathol. 37:99-112.

Revelo, X. S., and M. R. Waldron. 2010. Effects of in vitro insulin and 2,4-thiazolidinedione on the function of neutrophils harvested from blood of cows in different physiological states. J. Dairy Sci. 93:3990-4005

Rinaldi, M., P. Moroni, L. Leino, J. Laihia, M. J. Paape, and D. D. Bannerman. 2006. Effect of cis-urocanic acid on bovine neutrophil generation of reactive oxygen species. J. Dairy Sci. 89:4188-4201. Rinaldi, M., P. Moroni, M. J. Paape, and D. D. Bannerman. 2007. Evaluation of assays for the measurement of bovine neutrophil reactive oxygen species. Vet. Immunol. Immunopathol. 115:107125. 
Saad, A. M., and K. Ostensson. 1990. Flow cytofluorometric studies on the alteration of leukocyte populations in blood and milk during endotoxin-induced mastitis in cows. Am. J. Vet. Res. 51:16031607.

Sandgren, C. H., I. Larsson, and K. Persson. 1992. Bovine neutrophils recruited by endotoxin to a teat cistern continuously produce oxygen radicals and show increased phagocytosis and extracellular chemiluminescence. Inflammation 16:117-133.

SAS Institute. 2001. User's Guide: Statistics. 8th ed. SAS Inst. Inc., Cary, NC.

Sheppard, F. R., M. R. Kelher, E. E. Moore, N. J. McLaughlin, A. Banerjee, and C. C. Silliman. 2005. Structural organization of the neutrophil NADPH oxidase: Phosphorylation and translocation during priming and activation. J. Leukoc. Biol. 78:1025-1042.

Sohn, E. J., M. J. Paape, D. D. Bannerman, E. E. Connor, R. H Fetterer, and R. R. Peters. 2007a. Shedding of sCD14 by bovine neutrophils following activation with bacterial lipopolysaccharide results in down-regulation of IL-8. Vet. Res. 38:95-108.

Sohn, E. J., M. J. Paape, E. E. Connor, D. D. Bannerman, R. H. Fetterer, and R. R. Peters. 2007b. Bacterial lipopolysaccharide stimulates bovine neutrophil production of TNF- $\alpha$, IL-1 $\beta$, IL-12 and IFN- $\gamma$. Vet. Res. 38:809-818.
Sordillo, L. M., G. M. Pighetti, and M. R. Davis. 1995. Enhanced production of bovine tumor necrosis factor- $\alpha$ during the periparturient period. Vet. Immunol. Immunopathol. 49:263-270.

Vangroenweghe, F., I. Lamote, and C. Burvenich. 2005. Physiology of the periparturient period and its relation to severity of clinical mastitis. Domest. Anim. Endocrinol. 29:283-293.

Weber, P. S., S. A. Madsen, G. W. Smith, J. J. Ireland, and J. L. Burton. 2001. Pre-translational regulation of neutrophil L-selectin in glucocorticoid-challenged cattle. Vet. Immunol. Immunopathol. 83:213-240.

Worku, M., and A. Morris. 2009. Binding of different forms of lipopolysaccharide and gene expression in bovine blood neutrophils. J. Dairy Sci. 92:3185-3193.

Yu, C., Z. R. Shi, C. Y. Chu, K. H. Lee, X. Zhao, and J. W. Lee. 2010. Expression of bovine granulocyte chemotactic protein-2 (GCP-2) in neutrophils and a mammary epithelial cell line (MAC$\mathrm{T}$ ) in response to various bacterial cell wall components. Vet. J. 186:89-95.

Ziv, G., I. Hartman, E. Bogin, J. Abidar, and A. Saran. 1976. Endotoxin in blood and milk and enzymes in the milk of cows during experimental Escherichia coli endotoxin mastitis. Theriogenology $6: 343-352$ 